\title{
ISLAM IN INDONESIA
}

\section{Contrasting Images and Interpretations}

Edited by

Jajat Burhanudin and Kees van Dijk 
Islam in Indonesia 
(ICAS) Publications Series

\author{
General Editor \\ Paul van der Velde \\ Publications Officer \\ Martina van den Haak
}

\title{
Editorial Board
}

Wim Boot (Leiden University); Jennifer Holdaway (Social Science Research Council); Christopher A. Reed (The Ohio State University); Anand A. Yang (Director of the Henry M. Jackson School of International Studies and Chair of International Studies at the University of Washington); Guobin Yang (University of Pennsylvania).

The ICAS Publications Series consists of Monographs and Edited Volumes. The Series takes a multidisciplinary approach to issues of interregional and multilateral importance for Asia in a global context. The Series aims to stimulate dialogue amongst scholars and civil society groups at the local, regional and international levels.

The International Convention of Asia Scholars (ICAS) was founded in 1997. Its main goals are to transcend the boundaries between disciplines, between nations studied, and between the geographic origins of the Asia scholars involved. ICAS has grown into the largest biennial Asia studies event covering all subjects of Asia studies. So far six editions of ICAS have been held respectively in Leiden (I998), Berlin (200I), Singapore (2003), Shanghai (2005), Kuala Lumpur (2007), Daejeon, South Korea (2009) and Honolulu, Hawai'i (20II).

In 200 I the ICAS secretariat was founded which guarantees the continuity of the ICAS process. In 2004 the ICAS Book Prize (IBP) was established in order to create by way of a global competition both an international focus for publications on Asia while at the same time increasing their visibility worldwide. Also in 2005 the ICAS Publications Series were established.

For more information: www.icassecretariat.org 


\section{Islam in Indonesia}

\section{Contrasting Images and Interpretations}

Edited by

Jajat Burhanudin and Kees van Dijk 
(ICAS) Publications Series

Edited Volumes 16

Cover design: JB\&A raster grafisch ontwerp, Westland Layout: The DocWorkers, Almere

ISBN 9789089644237

e-ISBN 97890485 I 6254 (pdf)

e-ISBN 97890485 I 626 I (ePub)

NUR 7 I7

(C ICAS / Amsterdam University Press, Amsterdam 2013

All rights reserved. Without limiting the rights under copyright reserved above, no part of this book may be reproduced, stored in or introduced into a retrieval system, or transmitted, in any form or by any means (electronic, mechanical, photocopying, recording or otherwise) without the written permission of both the copyright owners and the authors of the book. 


\section{Contents}

$\begin{array}{ll}\text { Introduction } & 7\end{array}$

I Comparing different streams of Islam

Wrestling with words and definitions $\quad 15$

Kees van Dijk

2 Defining Indonesian Islam

An examination of the construction of the national Islamic identity of traditionalist and modernist Muslims

Ahmad Najib Burhani

3 Indonesia in the global scheme of Islamic things

Sustaining the virtuous circle of education, associations and democracy

Robert W. Hefner

$4 \quad$ Distinguishing Indonesian Islam

Some lessons to learn

Azyumardi Azra

$5 \quad$ Islam, state and society in democratising Indonesia

A historical reflection

Taufik Abdullah

6 The politics of piety in the Pondok Pesantren Khusus Waria

Al-Fattah Senin-Kamis Yogyakarta

Negotiating the Islamic religious embodiment

Dian Maya Safitri

7 The Indonesian Muslim feminist reinterpretation

of inheritance

Nina Nurmila

8 Managing familial issues

Unique features of legal reform in Indonesia

Euis Nurlaelawati 
9 A new generation of feminists within traditional Islam An Indonesian exception

Andrée Feillard and Pieternella van Doorn-Harder

Io Religious pluralism and contested religious authority in contemporary Indonesian Islam

A. Mustofa Bisri and Emha Ainun Nadjib

Asfa Widiyanto

II Islam and humanitarian affairs

The middle class and new patterns of social activism

Hilman Latief

I2 Dakwah radio in Surakarta

A contest for Islamic identity

Sunarwoto

I3 Muslim fundamentalism in education institutions

A case study of Rohani Islam in high schools in Cirebon

Didin Nurul Rosidin

I4 Majlis Tafsir Al-Qur'an and its struggle for Islamic reformism

Syaifudin Zuhri

Glossary

About the editors and contributors

Bibliography

Index 


\section{Introduction}

In recent years, the way Islam manifests itself in Indonesia has changed. As elsewhere in the Muslim world, there is stricter adherence to Islam, and fundamentalism has gained strength. An increasing number of Indonesian Muslims are observing the tenets of their religion more faithfully. More people fulfil the hajj, one of the basic pillars of Islam, and an increasing number of women wear a headscarf, sometimes a very fashionable one. These women include members of a segment of society that used to be considered the embodiment of secularism and syncretism, known in Indonesia as the abangan.

National surveys confirm this trend. In the last ten years or so, Muslims in Indonesia have become more religious in their attitudes and practices. The use of rituals associated with abangan culture has decreased, to be replaced by those of more observant Muslims, the santri. As a result, Islamic symbols and elements can be seen everywhere in Indonesian public life, including in liberal and capitalist institutions such as company offices and shopping malls.

The increasing emphasis on Islam is also reflected in the shifting position of fundamentalist groups. Since Suharto was forced to step down in the late I990s, Indonesia has witnessed a growing religious militancy. Not only have the militants increased in number, but they are also more actively engaged in missionary activities among fellow Muslims. Various radical organisations have emerged, including the FPI (Front Pembela Islam, Front of the Defenders of Islam), the MMI (Majelis Mujahidin Indonesia, Indonesian Council of Jihad Fighters) and the Laskar Jihad (Jihad Force). With a militant agenda of purifying Islam, these organisations are engaged in a series of violent acts against others, creating concern among moderate Muslims, who still form a majority in Indonesia. Their aspiration is to implement Islamic law in the public sphere, which in Indonesia is supposed to be religiously neutral.

The aims of these radical Muslim organisations are congruent with those of a number of Islamic political parties in parliament, while in some regions local administrations are trying to enforce proper Islamic conduct. The fatwa-giving commission of the MUI (Majelis Ulama Indonesia, Council of Indonesian Religious Scholars) - the institution en- 
trusted by the government with this task - and its regional chapters, at times also acts as the guardian of a strict interpretation of Islam.

Contributing to this trend has been the changing relationship between the state and Islam since around the turn of the century. After Indonesia became independent on I7 August 1945, its history as a nation is usually divided into three parts: the Old Order when Sukarno was President, the New Order when Suharto was in power, and the post-I99 8 period. The Sukarno years were coloured by antagonism between adherents of a religiously neutral state - or the Pancasila state, named after the five principles formulated by Sukarno in 1945 as the ideological foundation of political life - and the proponents of an Islamic state. A number of these proponents took up arms, fighting for an Islamic State of Indonesia (also known as the Darul Islam rebellion); others tried to realise their ideals through constitutional means by striving for a majority in the representative bodies. In the Constituent Assembly, the political institution tasked with defining the nature of the Indonesian state, those in favour of giving the Indonesian state an Islamic base and those against were more or less in balance. The deadlock this caused induced Sukarno to re-introduce the Constitution promulgated in I945, which mentions Pancasila in its preamble, on 5 July i959.

The period that followed was one of intense indoctrination of the Pancasila state ideology and increased domestic tension and repression. Deeply religious Muslims and the organisations that represented them were among those who suffered. Hard hit was Masjumi, the political party of the adherents of Islamic modernism, a stream of thinking that had reached Indonesia around the turn of the twentieth century and that had spread gradually and steadily. The government accused Masjumi leaders of siding with the Darul Islam and a second rebellion that took place in Sumatra and had regional rather than religious sentiments as its roots. Consequently, Masjumi was banned in I960. The large modernist socio-religious organisation, Muhammadiyah, was allowed to continue to exist, as was its traditionalist counterpart, the Nahdlatul Ulama; but it became impossible for the leaders of either organisation to publicly criticise government policy in any field.

Suharto's New Order brought some relief, but only partially so. The generals who came to power in I965 were highly suspicious of political Islam and the Masjumi. The authorities introduced a new term - right extremism - for political Islam and for demands for a state based on syariah instead of Pancasila. Only those fundamentalist groups that kept clear of politics and did not question Pancasila as the basis of the state were tolerated. Speaking out against the national ideology meant imprisonment or life in exile, if not worse. Masjumi remained a forbidden party. Banned from politics, as a number of the contributions to 
this book explain, a number of its leaders decided to concentrate their efforts on propagating their strict interpretation of Islam, stimulating the spread of such ideas. A similar mechanism was at work in the universities, especially the secular ones. With students forbidden from engaging in political activities, the campus mosques became centres of religious activity.

Government policy culminated in 1985 when, on pain of being banned, all organisations and political parties, including the religious ones, were obliged to acknowledge Pancasila as their asas tunggal, their 'only basis'. Rather naively, the government concluded from the general compliance that Pancasila was safe. For Suharto, this was a reason to allow greater participation by devout Muslims in politics and for the introduction of measures intended to placate the Islamic community, such as the establishment of an Islamic bank and the 'compilation' of Islamic family law.

President Suharto was forced to step down in May I998, and the Reformasi (Reform) period began. Full freedom of speech and of association was stressed as being among the most important achievements of this new political era. Muslims persecuted for their religious ideas were released from prison or returned home from exile. The asas tunggal became irrelevant. People were allowed to campaign for the establishment of an Islamic state. Some propagated Islamisation 'from above' that is, the establishment of an Islamic state and enforcement of Islamic legislation. Others made reform of society, not of the state, their principal aim, concentrating on winning over the population to their ideals before implementing Islamic law.

Pancasila has maintained its importance. Most Islamic political parties, including the PKS (Partai Keadilan Sejahtera, Prosperous Justice Party), a new popular Islamist party, acknowledge Pancasila and reject the idea of transforming Indonesia into an Islamic state. At the same time, more than ever, secular parties emphasise that Islam also matters to them and to their members and voters, and they even join forces with their Islamic counterparts in certain regions or on certain issues. This has given some of the new legislation on the national and regional levels a distinctly fundamentalist Islamic stamp.

Religious debate has changed and intensified. In part, this is because new hard-line groups are allowed to publicly attest to their radical ideas. Some of these - the above-mentioned FPI, MMI and Laskar Jihad - do not shrink from violence. Zealously defending what they consider to be true Islam, they vehemently protest against people and groups who are seen as a threat to Islam or in their eyes betray Islam, such as members of the Ahmadiyah, or those they accuse of breaking the rules of moral conduct that should be upheld in public. At times, they also make it impossible to hold services at Christian houses of 
worship, which they claim have been built without the requisite permits. Members of the FPI and like-minded groups may be in the forefront when it comes to physical attacks on those whom they have identified as the main enemies of their religious convictions. Their rowdy demonstrations and raids - including raids on pubs and discotheques - often go unchecked, with the authorities and police hesitant to act or to protect the targets of their fury; either because they sympathise with the protests, are afraid to act, or simply cannot decide which measures should be taken. This gives such groups greater influence than their numerical strength would warrant.

A telling example is the visit to Indonesia by the Canadian author Irshad Manji to promote her book, Allah, Liberty and Love (banned in Malaysia), in May 2012. Book presentations in Jakarta and Yogyakarta were raided by hardliners of the FPI and other groups, or cancelled by the authorities. One signing, organised by the Jakarta branch of the Alliance of Independent Journalists (AIJ), did proceed, but only after its organisers had enlisted the help of Banser, a youth group usually employed to provide security at Nahdlatul Ulama events. When fundamentalist Muslims - and in this respect, the MUI and its local chapters must also be mentioned - speak out against individuals, groups or activities, there is a fair chance that their demands will be met. In May 20I2, for instance, protests by the MUI, the FPI and like-minded groups resulted in the Jakarta police refusing to issue a permit for a planned concert by Lady Gaga. The national police, the final authority on the matter, made permission dependent on a positive recommendation by the Ministry of Religious Affairs and the MUI - a recommendation that both refused to give. In the end, Lady Gaga's management cancelled the concert.

Irshad Manji does not hide the fact that that she is a lesbian, and the fact that Banser facilitated the AIJ meeting is an indication of the complexity of Islamic relations in Indonesia. The proselytising nature of Salafi and other Islamist groups poses a challenge to long-established, large socio-religious organisations such as Muhammadiyah and the Nahdlatul Ulama. Islamists condemn some of the religious practices and beliefs of the latter and try to win over their members and followers, competing for control of mosques and other religious institutions. At the same time, radical Muslims and a section of Muhammadiyah and the Nahdlatul Ulama membership may find common ground in their rejection of liberal or progressive Muslims, often young intellectuals and graduates from Islamic universities whose opinions about tolerance, justice and equality (including gender equality) they detest. These two factions can also unite on other issues. Leaders of Muhammadiyah and the Nahdlatul Ulama are members of the MUI, and may sit on the boards of hard-line groups. Their fundamentalist 
ideas do not go unchallenged. Religious debate has become very lively, especially due to the fact that progressive Muslims who refuse to accept the strict fundamentalist interpretations propagated are making themselves heard.

How to interpret such recent developments is a topic of debate. Islam in Indonesia, characterised by its moderation and tolerance, has been held up as a model for other Muslim nations. Does this image still hold? The very visible presence and activities of radical groups have led some to conclude that Indonesian Islam is losing its moderate disposition. This is a topic of debate in Indonesia itself, and among foreign scholars and observers. In a statement about the commotion surrounding her visit to Indonesia, Irshad Manji was quoted in the Jakarta Post (II May 20I2) as saying that four years earlier, she had experienced Indonesia as 'a nation of tolerance, openness and pluralism', and that in her book she 'described Indonesia as a model for the Muslim world'. She suggested that Indonesia had changed since her last visit, which was not in fact the case. Journalists also express their unease over the fact that the uncompromising stand taken by some Indonesian Muslims is in contrast to the peaceful and tolerant Islam with which Indonesia is often associated. In reports about mob violence or the activities of certain Islamic groups in Indonesia in English-language Indonesian newspapers or newspapers published abroad, it is now common to find journalists explaining that the vast majority of Indonesian Muslims are moderate and tolerant, and that it is only a fringe minority that acts and thinks differently.

The variety of manifestations of Islam in Indonesia and the ongoing discussion between representatives of different streams of Islam this implies formed the inspiration for this book. It brings together a selection of papers presented at the conference entitled 'Is Indonesian Islam Different? Islam in Indonesia in a Comparative International Perspective', held in Bogor, Indonesia in January 20II, and organised by the Center for the Study of Islam and Society of the UIN Syarif Hidayatullah, Jakarta, and the Training Indonesia's Young Leaders Programme of Leiden University.

The contributions are arranged in three sections. In the first section, some general questions and evaluations are presented. Kees van Dijk and Ahmad Najib Burhani discuss how we should understand the use of the term 'Indonesian Islam'. Robert B. Hefner and Azyumardi Azra identify the specific accomplishments of the Muslim community in Indonesia. Hefner concentrates on the prominence of long-established welfare associations, the dynamics and openness of its educational system, and the early consensus that Islam and constitutional democracy are compatible. Azyumardi Azra also calls attention to the peaceful spread of Islam in Indonesia, the accommodation of local tradition, 
and the position of women in Indonesian society. In the final article in this section, Taufik Abdullah explores the response of Muslims during Suharto's New Order, when Islamic organisations were denied a significant role in politics, and the emergence of networks of liberal young Muslim intellectuals and religious thinkers promoting tolerance and pluralism in the period of 'openness' that followed.

The second section deals with liberal interpretations of Islam and humanitarian activities, topics that tend not to get much coverage because of the massive attention that is given in Indonesia and elsewhere to manifestations of intolerance. Dian Maya Safitri sketches life at an Islamic religious school for transgenders and transsexuals. Nina Nurmila challenges the literal approach to the Qur'anic verses on inheritance division, according to which a male always receives twice as much as a female, because it does not take into account the difference in kinship systems in the Middle East and Indonesia and the current context of Indonesian gender relations. Euis Nurlaelawati analyses the reforms in family law introduced in the Suharto era and investigates whether judges in Islamic courts follow them in cases in which they have to decide on allowing polygamy. In their contribution, Andrée Feillard and Pieternella van Doorn-Harder focus on the activities of Indonesian Muslim feminists, especially those from the Nahdlatul Ulama, and the challenges they face. They argue that these Muslim feminists play a pivotal role. Their thorough religious education equips them to enter into religious gender debates from which secular feminists, lacking such a background, tend to shy away. Central to Asfa Widiyanto's plea for religious pluralism in Indonesia are two Sufi-inspired men of letters, Mustofa Bisri and Emha Ainun Nadjib, who do not hesitate to speak out against intolerance, but who are still respected in Islamist circles due to their renown as Islamic scholars. The section concludes with a study by Hilman Latief on the growth of a new Islamic middle class in Indonesia, its role in modernising Islamic social activism, and the development of middle-class, faith-based humanitarian associations.

In the final section, the focus turns to Salafi groups and their way of operating and recruitment. Sunarwoto examines Islamic radio stations in Surakarta, one of the centres of Islamic radicalism in Java, and their different interpretations of what Islamic radio stations should broadcast. Didin Nurul Rosidin compares the activities of two Islamic student associations at two Senior High Schools in Cirebon, West Java. Finally, Syaifuddin Zuhri reports on his research on a Salafi group in Surakarta, and the modern and traditional communication networks it uses to propagate its fundamentalist ideas.

Concomitant with the growing emphasis on Islam in Indonesia has been not only the spread of Arabic expressions and technical Islamic 
terms but also the desire by some to use the correct transliteration. For example, it is not unusual to find different authors spelling the same word differently. This diversity has been maintained in this volume. The same approach has been taken to the spelling of personal names and names of organisations, where the spelling reforms of 1947 and I972 have left their mark.

Finally, our appreciation goes to the organisers of the Bogor conference and to Anna Yeadell, who corrected the English of the contributions presented in this volume. 


\title{
8 Managing familial issues
}

\section{Unique features of legal reform in Indonesia}

\author{
Euis Nurlaelawati
}

\section{Introduction}

Indonesian state law on Muslim familial issues, as embodied in Marriage Law No. I/I974 and Presidential Instruction No. I/I99I regarding the Compilation of Islamic Law (Kompilasi Hukum Islam), introduced a number of reforms reflecting the inclusion of local customs, state interests and new issues in Islamic discourse in Indonesia, including gender issues. By doing so, it attempted to achieve an amalgamation of the classical legal doctrines of Islam, state interests and local tradition or adat. The accommodation of local tradition and state interests makes the law distinctly different from similar laws issued elsewhere in the Muslim world. The rules on representation of heirs, obligatory bequest (wasiat wajiba) and joint property are examples of the special characteristics of Indonesian law in this field. The distinctive features become even stronger when we look at how judges deal with family law.

This chapter examines how Indonesian state law addresses issues of Muslim family law by looking at specific questions relating to reforms. It discusses some examples of reform by observing the key concepts and interpretations of Islam used in drafting the new rules. It then compares the results with laws introduced in other Muslim countries in order to draw attention to similarities and differences and to analyse the factors that underlie the uniqueness of the Indonesian approach.

\section{Ideas of reform in Islamic family law}

The introduction of Islamic principles into national law has been a topic of discussion since Indonesia became independent in 1945. Indonesian Muslims now have what has come to be called the Kompilasi Hukum Islam, henceforth referred to here as the kompilasi. Issued in I99I, the kompilasi systematises and brings together in one book the Islamic legal rules regarding family law derived from various fiqh 
texts. Its compilation is one of a number of remarkable examples of the trend of legal codification in the Muslim world. The kompilasi is divided into three volumes on marriage, inheritance and endowment respectively. Its issuance by the Indonesian government complemented the reform of the religious judicial system in Indonesia, which had previously seen the ratification of the Religious Judicature Act in 1989 as the formal law regulating the position of religious courts within the national legal system and their composition, jurisdiction and procedures.

From the perspective of legal development, this piece of state legalisation - which should now, it is being proposed, be amended and reissued as two separate laws, one on marriage and one on inheritance reflects a long struggle by Muslims for the application of Islamic law in Indonesia. The preliminary efforts took place in the I950s and early I96os, when Hazairin and Hasbi al-Shiddieqy had the idea of establishing an Indonesian school of Islamic law (Feener 2002; Nurlaelawati 20I0). In the I980s, the agenda emerged again when Munawir Sjadzali suggested the re-actualisation of Islamic law, which developed in the direction of the unification of legal references in the religious courts (Nurlaelawati 20I0).

The kompilasi owes its origins to the idea of formulating a distinct Indonesian school of Islamic law, as proposed by Hazairin (I905-I975). A scholar of both Islamic and adat law at the University of Indonesia, Hazairin sought to bridge the gap between the two by advocating the development of a distinctive body of Islamic law. He was convinced that the reform of Islamic law was not an individual matter but rather a collective task to be completed by representatives of the community, working in close partnership with the state. He wanted to see problems in the Muslim community solved by formal institutions with the authority to act on religious issues (Feener 2002).

Hazairin's ideas were too radical and extreme for the majority of Indonesian Muslim leaders, and inevitably elicited opposition. In fact, they got no positive response until I96I, when Hasbi ash-Shiddieqy, a professor at the State Institute for Islamic Studies (IAIN) in Yogyakarta, argued the need to establish a new school of Islamic law that took greater account of Indonesia's social and historical context (Yudian Wahyudi i993). Hasbi thought that what had traditionally been considered as Islamic law among the founders of the madhhabs should actually be considered 'Arab fiqh'. In this context, he argued that Islam could only remain a vital source of guidance in the lives of Indonesian Muslims when the methods of understanding scripture and law could be re-conceptualised in accordance with the specific conditions and current needs of Indonesian society. For this purpose, he called for a new and more directly relevant method in order to achieve the appropriate 
interpretation and application of principles from the original source to particular cases and conditions (Feener 2010).

Hasbi and Hazairin's visions on the formulation and application of Indonesian fiqh emphasised a sense of Indonesian-ness, in terms of both the specific local conditions prevailing in Indonesia and the particular character of the Indonesian state, especially in relation to its legal policy base, Pancasila, the ideology of the state. There is no doubt that these ideas are a reflection of the thinking that lay at the core of the Islamic legal discourse at that time. Although they gained no widespread acceptance at that moment and no support from the Sukarno regime - which in the context of the political competition that was rife in those years tended to see Islam as a threat and even introduced a number of repressive policies to control Islamic groups - their ideas helped to lay the groundwork for the development of Islamic law in the ig8os (Nurlaelawati 2010).

The idea of formulating a distinct Indonesian school of Islamic law proposed by both Hasbi and Hazairin seems to have taken on new life in the I980s. It fell within the scope of the re-actualisation of Islamic teachings proposed by a prominent and high-ranking Muslim and statesman, Munawir Sjadzali (1925-2005). Sjadzali had served as a long-time senior official in the Department of Foreign Affairs before his appointment as Minister of Religious Affairs in two consecutive cabinets of the New Order (1983-I993). His ideas gained significance in the new wave of Muslim intellectualism during the New Order, born out of the need to deal with the failure of Muslim leaders to realise their political agendas in the early years of the Suharto regime (Effendi I995).

Looking specifically at the development of Islamic law, Sjadzali's proposals can be understood from an examination of his discussion on the principles of Islamic inheritance, particularly in relation to the share received by children of the deceased. The stipulation of the Qur'an that a son should inherit twice as much as a daughter was, according to him, in some circumstances, contradictory to the very notion of justice. Sjadzali argued that the rule mentioned in the Qur'an that a female should receive only half of that of a male from an estate - was not a final decision, as giving females and males an equal share would have shocked the Arab society of the time, which had denied women any inheritance prior to the introduction of Islam. It must be pointed out here that one of the principles for completing the establishment of Islamic law is that changes in the law have to take place gradually. Given that reform in the establishment of Islamic law takes place gradually (tashri ), it is argued that the rule that a woman should only inherit half the amount a male gets is not yet the final rule (Saimima I988; Nurlaelawati 20I0) and that it still requires completion. 
The above discussion reflects the evolution of the idea of applying Islamic law in Indonesia in relation to the changing attitude of the state towards Islam. Munawir Sjadzali's plea for a re-actualisation of Islamic law was clearly a continuation of Hazairin's and Hasbi's suggestion that a distinctly Indonesian school of Islamic law should be established. Sjadzali attempted to give new resonance to this suggestion after the state had succeeded in reinforcing its domination over Muslims, as proven by the acceptance of Pancasila as the sole national ideology by Muslim organisations in the mid-I980s. These three scholars have provided a basis for the various attempts to ensure that Islamic law is included in the legal system of the state. It is within this context that the idea of putting together the kompilasi has been advanced.

The kompilasi could be realised because of a shift in state policy towards Islam, which coincided with the fact that many Muslim leaders at that time had abandoned the idea of establishing an official Islamic state and were content to pursue a gradual Islamisation of the country. In terms of the realisation of Islamic law, they no longer spoke of a general but only a partial realisation - that is, the application of certain elements, including matters concerning family life. They strove to integrate the principles of Islamic law into national law through regulations issued by the government.

\section{Legal reforms}

As explained above, the Indonesian government has developed law on the basis of shari'a through the Kompilasi Hukum Islam. Although on most issues, the kompilasi generally adopts classical Islamic legal doctrines, especially that of the Shafi'ite figh texts, it also introduces a number of reforms. These reflect the inclusion of local customs, state interests and new issues in Islamic discourse in Indonesia. By doing so, the kompilasi is an attempt to achieve an amalgamation of the classical legal doctrines of Islam, state interests and local tradition or adat. There can thus be no doubt that the drafters of the law realised that the plurality of legal norms in Indonesia could not be ignored. By accommodating local customs, giving the state a place and paying due attention to gender equality and other new issues, they apparently sought to demonstrate that these domains can be integrated into the practice of Islamic law and do not stand in isolation from one another (Nurlaelawati 2010).

The influence of adat or local norms is most apparent in a number of rules in the kompilasi concerning inheritance. Although the kompilasi generally adopts the traditional fiqh doctrines and incorporates all relevant Qur'anic texts (Cammack I999), it applies a system of repre- 
sentation of heirs and obligatory bequests that cannot be found in any classical fiqh texts. The system of representation of heirs, for example, was adopted to solve the problem of orphaned grandchildren, whose parents predeceased their own parents. According to the classical Islamic system of inheritance, orphaned grandchildren are excluded from shares in their grandparents' estates. All schools of Islamic law agree that an orphaned grandchild has no right to a share from his or her grandparents when there are other living children (sons). Following this rule, all Muslim countries, including Indonesia, have denied the predeceased heirs and their heirs or descendants any share of an inheritance as long as there are other living sons. It is believed that there have been a number of victims of this decision (Carol I998; Mehdi I999).

As there is a prevailing sense that it is unjust to deprive orphaned grandchildren of their right to the estates of their grandparents simply because their parents have died earlier, some countries, including Egypt, Morocco and Indonesia, have attempted to redress this inequity. Two solutions have been proposed: namely, obligatory bequests and a system of inheritance by right or representation of heirs. The former was first adopted by Middle Eastern countries, the latter by Pakistan (Mehdi I999) and subsequently by Indonesia.

Besides adopting adat, the kompilasi also includes interests of the state. One example is the rules on marriage registration. According to the classical doctrine of Islamic law, a marriage is considered lawful when it is concluded with an offering by the female guardian and its acceptance by the male (husband) in the presence of witnesses. Two Muslim males or one male and two females are required to witness the contract of marriage (Dawoud I992). There is no need for a contract of marriage to be registered, but the kompilasi states that a marriage should be concluded in the presence of an official marriage registrar or must be registered. Failure to register a marriage affects its validity, and judicial relief such as divorce and inheritance assessment is denied in the case of an unregistered marriage. This means that the kompilasi allows no room for unregistered marriages.

Keeping pace with the growing demand for gender equality, the kompilasi also strives to heed women's interests, paying special attention to polygamy and divorce, issues that are still hotly debated by Muslims. This specific attention ties in with the state agenda to empower women via a programme of economic development. In Indonesia, the issue of polygamy has long attracted considerable attention from women activists. Efforts have been made to have it prohibited or, failing that, at least to restrict its arbitrary practice. Various seminars on this issue have been held by Muslim women's organisations (Nurlaelawati 20IO). These protracted struggles only gained a positive response from 
the government in the I970s. With the ratification of the I974 Marriage Law, the Indonesian government placed limits on the practice of polygamy by laying down a number of conditions for the legal conclusion of polygamous marriages. ${ }^{\text {I }}$

\section{Unique features: some examples}

\section{Registration of marriage}

The kompilasi states that a marriage must be concluded in the presence of an official marriage registrar or that it must be registered. However, it does differentiate between the religious validity and the state legality of marriage and therefore does not deem a marriage religiously invalid if the parties concerned fail to register their marriage (Bowen 2006). In fact, while considered illegal by the state, unregistered marriages are not seen as unlawful by the religious authorities. It seems clear that the kompilasi is anxious not to deviate from the classical doctrine of marriage. This is different from the situation in other Muslim countries, such as Iran: in this country, which follows the Shi'ite legal school, registration is obligatory and failure to do so invalidates a marriage in terms of religion (Nurlaelawati 2010).

The kompilasi seems to have applied the concept of 'dual validity' to preserve the view of classical Muslim scholars that only religious requirements can decide whether or not a marriage contract is valid. ${ }^{2}$ Therefore, the registration of a marriage cannot be considered the main factor in deciding the religious validity of marriage. It is only an administrative requirement. This can be understood from two different articles, one of which states that registration is a necessity and the other that a marriage is considered valid if it meets all requirements defined by religion.

Indeed, this concept emerged as the result of a compromise between the traditionalists and the modernists, and inevitably it still fuels debates among Muslim scholars in Indonesia. Positioning registration as a purely administrative matter, the kompilasi makes no mention of sanctions for those failing to comply. The i975 regulation elucidating the application of the Marriage Law does so, but only with regard to the registrars. It states that should a registrar fail to register a marriage, he will be fined Rp. 7,500. However, the document is rather vague in specifying under what conditions a registrar failing to register a marriage has to pay a fine.

Although the position taken by the kompilasi is, to some extent, the same as that taken in other Muslim countries, on some points it is quite unique. Malaysia also requires the registration of a marriage but avoids ambiguity and dualism. There, it is clearly stated in law that an 
unregistered marriage is considered valid. According to Malaysian legislation, registration functions merely as an administrative requirement and has nothing to do with the religious legality of the marriage. Couples that fail to register their marriage can be punished with a sixmonth prison sentence or a maximum fine of one thousand ringgit.

The kompilasi is now being amended, and it is proposed that those who fail to fulfil a number of requirements, including the registration of a marriage, are liable for punishment. While some scholars agree with this, many argue against it. Those who do not support it include traditionalist as well as modernist Muslims.

\section{Inheritance: wasiat wajiba and the representation of heirs}

In terms of inheritance rules, the kompilasi introduces two novel concepts; namely: obligatory bequest (wasiat wajiba) and the representation of heirs, which are rules that are deployed to resolve the problem of orphaned grandchildren in the Muslim world. While Middle Eastern countries use wasiat wajiba as a solution, Indonesia and Pakistan have adopted the concept of the representation of heirs.

However, unlike Pakistan, Indonesia makes the rule quite complicated and confusing. The relevant article in the Muslim Family Law Ordinance of 1965 states that a predeceased son or daughter can be substituted by his or her living children (Mahmood I987), thereby regulating the problem of inheritance by orphaned grandchildren. The article in the kompilasi is less clear. It states that deceased heirs can be substituted by their children (ahli waris yang meninggal terlebih dahulu dari pewaris dapat digantikan kedudukannya oleh anaknya). The use of the general term ahli waris has resulted in multiple interpretations. It can refer to any person in a family. It can refer to a child, a child of collaterals (nephew) and other relatives of the deceased. Judges have indeed applied these multiple interpretations, resulting in decisions that have awarded a share to nephews, for example. Decision No. 0259/Pdt.G/ I992/PA.JP issued by the Central Jakarta Court is an example of such a case (Nurlaelawati 2010).

To add to the confusion, the introduction of these two concepts in the kompilasi is somewhat peculiar in the sense that, in the case of representation, an additional rule has been introduced: namely, a limitation on the share of the representative heir. This is something that Pakistan, which has adopted the same doctrine, has not done. The additional clause mentions that the share of the representative heir may not exceed that of the heirs whose position is equal to that of the representative heir. This clause emanates from the fact that the kompilasi preserves the established ratio of 2:I with regards to the shares of 
males and females. It has therefore been assumed that the application of the representation of heirs may generate complications. ${ }^{3}$

The concept of wasiat wajiba, which is used by countries in the Middle East to solve the problem of predeceased heirs (orphaned grandchildren), is applied by the kompilasi to grant an adopted child a share of his or her adoptive parent's estate and an adoptive parent a share in that of his or her adopted child. However, this is only possible when a child or parent leaves no will. By using this concept, the kompilasi aims to avoid the 'pure' practice of inheritance among adoptive and adopted parties, as practised among Indonesians, especially the Javanese. At the same time, it does not fully ban such practices. Adoption is popular among Indonesian families. In spite of the variations in application from one society to another, several principles are uniformly embraced. These principles rule that the adopted child is automatically included in the circle of the adoptive family, that the relationship of the adopted child to his or her biological parents is severed, and that the status of the adopted child is equal to that of a biological child.

The drafters of the kompilasi sensed that although the full attribution of adopted children to their adoptive parent or vice versa may be disallowed, as it contradicts the Qur'anic text, (which clearly undermines the full attribution of an adopted child to his or her adoptive parents or vice versa), the tradition of inheriting from each other should be retained. They argued that it would not be fair if each of the parties were to be left with nothing when the other party died. However, they thought that the system by which the adoptive parties could give and receive each other's estate should not be the same as the system of inheritance for biological children. To avoid or eliminate the practice of giving and receiving an estate under the 'pure' system of inheritance between adoptive parties, on the one hand, and to grant them a share from each other on the other, they decided that the institution of obligatory bequest be applied (Nurlaelawati 2010).

\section{Why unique? A critical review}

It is safe to say that, along with a number of other countries, in Indonesia it is believed that familial affairs are best managed by the state. On certain issues - namely, dealing with a bilateral system and creating justice and equality for women and other vulnerable persons - Indonesia has adopted a unique position. This, in my view, is the result of a number of factors, including the incorporation of local features and the preservation of traditionalism in written law. The uniqueness is strengthened by a biased interpretation of the law and the ambigu- 
ous attitude of some judges and Indonesian Muslim organisations, which have resulted in the glorification of the notion of ijtihad and the expression of amr ma'ruf nahy munkar (enjoining good and forbidding evil) by some Muslim groups.

\section{Local features}

Indonesian legal reforms are unique, to a certain degree, because they accommodate elements of adat. The 'joint property' rule constitutes one example. The principle of joint property (harta bersama, harta gono gini) is not dealt with in any classical Islamic legal doctrine. It is, however, internalised in the social life of Indonesian society. To accommodate this local practice, Indonesian state law administers that a husband and a wife who are bound in a contract of marriage have an equal right to property acquired during their marriage. When the marriage is ended, each of them is entitled to an equal share of that property. Although Malaysian law also deals with this matter, the institution of joint property is to some extent typical of Indonesian culture.

This special feature can be traced back to the fact that in Indonesia, it is common for both the husband and the wife to work outside the home, although it is acknowledged that the husband is the head of the family. In Solo, for example, women generally earn money from multifarious activities. In families that run a home industry such as membatik (traditional designing and printing on cloth), for instance, women play an important role. They buy the cloth, design the patterns and even manage the firm (Saimima 1988). Likewise, in other regions, women do not just stay at home but go to farms, markets and other places to earn their own living. In due consideration of this, it would be unreasonable for a wife to be left with nothing when her marriage ended, while her husband had full rights to their property. Aside from gono gini, other popular terms refer to the existence of the institution of joint property, such as harta papantangan in Kalimantan and harta sahareukat in Aceh, proving the strength and unique character of this rule.

Another issue that demonstrates the uniqueness of Islamic legal reform in Indonesia is the adoption of the rule of representation of heirs, as discussed above. The application of the rule is in accordance with the practice of giving a right of inheritance to orphaned grandchildren, which was established in certain Indonesian Muslims circles through the system of plaatsvervulling, a Dutch term meaning inheritance by right of representation. In Medan in I950, the Appellate General Court even ruled through its decision No. I95/1950 that when a child of a deceased heir has died before the deceased, and the former has left be- 
hind a child or children, the children of the child or the grandchildren of the deceased have a right to the deceased's estate on behalf of their father. The same decision was issued by the Civil Court (Raad van Justitie) of Batavia on I2 December I932, as recorded in Indisch Tijdschrift van het Recht (Nurlaelawati 20I0). This means that the system of representation of heirs is not completely new in Indonesia. Although it constitutes a widespread problem in many Muslim countries, it has a local foundation in Indonesian legal practice.

As mentioned above, the limitation rule in the application of the representation of heirs has strengthened the uniqueness of Islamic law in Indonesia. Furthermore, it has given an extra edge to the debate. Coupled with the fact that the issue has been ineluctably practised in Indonesian society, the rule of representation of heirs has turned the debate towards a more principal point - that is, the question of whether it is Islamic or adat law that provides the basis for the maintenance of the practice. Or, in other words, has adat adapted to Islam or vice versa?

Bearing in mind that the majority of Muslim scholars agree in principle with granting a share of the deceased's estate to orphaned grandchildren and have chosen the institution of wasiat wajiba to deal with this matter, I arrive at the question of why the kompilasi favours the concept of the representation of heirs over the institution of wasiat wajiba to solve the problem of grandchildren? I assume that the drafters of the kompilasi realised that there was yet another problem that needed to be solved - namely, that of adoptive parties. Having decided that the matter of adoption could not be solved by the concept of the representation of heirs, they chose to employ the concept of the representation of heirs to tackle the issue of orphaned grandchildren. At the same time, they preferred to apply one solution to one problem rather than apply one and the same solution to two problems by, for instance, using the legal concept of obligatory bequest to solve the separate problems of orphaned grandchildren and adoption. With their minds firmly set on this path, they insisted on applying the principle of the representation of heirs, despite its lack of rationale in Qur'anic texts, to the problem of orphaned grandchildren, and obligatory bequest to that of adoption.

\section{The persistence of traditionalism: ambiguity on paper and in practice}

It is widely acknowledged that Indonesian Muslims have diverse religious backgrounds. When the reforms in family law propagated by the state were to be amended, many felt obliged to contribute their opin- 
ion. They included representatives of traditionalist and modernist groups as well as feminists. This is understandable, as the reforms had already been debated for a long time.

The state law introduced a number of reforms. However, most of the articles adopted opinions of the 'ulama, as set out in figh books. While some traditionalists state that the reforms are too radical and deviate too far from the fiqh texts, feminists have branded the state law conservative. They claim, for example, that some articles, such as the one that states that a husband can house his two wives in one house, are barbaric and maintain the subordination of women. They also point to the article on wives giving their permission for polygamy. This article discounts the need for permission when wives are unable to give it, either due to their absence or their inability to decide (Mulia 2007).

Some articles are also quite vague. This is illustrated by the rule on the registration of marriage, as mentioned above. It seems that the changes are ambiguous and that the reforms lack clarity. On the one hand, the reformers revelled in the winds of reform and it was their intention to see marriages well managed. On the other hand, they lacked the bravery to deviate from and go beyond the shari'a line. The fact that in Indonesia, modernists and feminists hold different opinions might be one reason for this ambiguity.

The position taken by the Indonesian reformers on this and other issues is quite different from that of their counterparts in Malaysia and Pakistan, who were firmer and clearer in formulating legislation. While pro-reform, they remain on the side of traditionalists by stating that a marriage is considered valid even if it is not registered. Meanwhile, Indonesia tends to side with the modernists, but not wholeheartedly. This has resulted in the blurring of rules and uncertainty in judicial transactions.

Not only are ambiguity and dualism present on paper, they are also evident in the work of judges. In the case of polygamy, such attitudes are very clear. For my recent research, I collected nine judgements on polygamy issued between 2007 and 2009 by the Religious Court of Cianjur. All of them show that the court approved every petition for polygamy. The motivations for this varied, according to the reasons advanced by the petitioners (husbands). They ranged from the inability of the wives to give birth to children and acute illness to high sexual desire on the part of the husband. High sexual desire is the dominant reason for the petitions.

These judgements clearly indicate that the judges of this court are not strict in their application of the rules, a finding that concurs with the results of a survey I carried out for my doctoral thesis. ${ }^{4}$ For example, one judgement, No. 290/Pdt.G/2008/PA.Cjr, demonstrates that the judges appear to have supported the husband involved in his bid to 
marry more than one wife in order to avoid zina (adultery), as the husband had a high sexual appetite. They endorsed his plea that the wife had to accept the decision taken by her husband. Judgement No 22I/ Pdt.G/2008/PA.Cjr shows the same judicial adherence to the classical legal doctrine on polygamy and neglect of the codified rules restricting polygamy, and the demand that a request must be based on the appropriate reason specified in the rules.

Although in some courts, judges have been found to be receptive (Salim et al. 2009), ${ }^{5}$ it seems to me that gender sensitivity has not increased evenly among the judges of religious courts. Their approval of petitions based on other grounds, such as the inability of wives to bear children, seems to strengthen this assumption. Judges frequently fail to consult medical specialists to establish whether or not a woman can give birth, and instead just rely on the information given by the petitioners, which is sometimes supported by their wives. Judgement No.255/Pdt.G/2008/PA.Cjr is a case in point. This is not an exception, however, as many other judges seem to have acted in similar ways. Besides judgements issued by the Religious Court of Cianjur, I also collected judgements issued by two other religious courts, those of Serang and Tangerang in Banten. From the 45 judgements issued by the court of Serang on various cases, five were on polygamy. In four of these, the petition for polygamy was approved on the grounds of the high sexual desire of the petitioners (husbands).

Indonesia has ratified a number of international treaties dealing with gender issues, but many judges seem to be unaware of them. One, the Convention on the Elimination of All Forms of Discrimination against Women (CEDAW), stresses the protection of women's rights, and Indonesia concurs with a number of points mentioned in the convention. Nonetheless, it seems that rather than referring to such conventions, judges tend to consult fiqh doctrines and Quranic verses, even though such verses require interpretation. Some researchers conclude that judges have applied the rules of the kompilasi or the state law well, and to some extent, I agree with them (Sabri 200I; Sumner \& Lindsey 20I0). ${ }^{6}$ However, judicial attitudes to international conventions on women's rights suggest that aspects of the kompilasi are being applied in an ad hoc way. This can be seen, for example, in the responses of those judges who argued that they did not have to investigate whether or not the consent of the wife had been given sincerely. In addition, they did not feel obliged to check whether a husband really had a high level of sexual desire or to verify whether the husband's current wife was really unable to bear children. Above all, most of the judges emphasised the conditions to be met by husbands when making their judgements rather than examining the reasons why husbands wished to marry more than one wife. Consequently, they often accepted any 
reason presented by husbands, even those not included in the laws. The concept of maslahah (public good) figured prominently in their legal considerations. Some judges agreed to give permission, stating that denial would result in the husbands having extramarital sex.

\section{The glorification of the notions of ijtihad and amr ma'ruf nahy munkar}

There is indisputable evidence that the legislated kompilasi text is still considered an 'open' text. As is also the case with codes enacted elsewhere, although the open character once attributed to the figh texts has been curbed and change is only possible if it is introduced by legislative amendment (Messick I993), interpretative modification by individual scholars and by official authors of Islamic law, such as judges, is still envisioned. And while, like other codes, the kompilasi also implies replacing the single authorship of the old fiqh texts by a plural legislative voice, the authoritative manual opinion thereby being ousted by the authoritative code article, the fiqh texts and their legal doctrines have become so institutionalised in the Indonesian Muslim community that it is impossible for this new code to replace them entirely. In short, taking all these hurdles into consideration, some judges seem to be preserving traditionalism and conservatism through their ambivalence towards the kompilasi.

The decisions of the judges of a number of religious courts on cases of polygamous marriage clearly demonstrate that judges sometimes dare to take a controversial decision on the basis of performing ijtihad. As mentioned, the kompilasi enumerates the reasons for and conditions under which a man can enter into a polygamous marriage. The judges of one court, however, gave a man permission to enter into such a marriage on grounds not mentioned in the kompilasi - namely, that he was asked by his second wife to protect her and her wealth. The woman was a rich widow who had no relatives to whom she could turn for help. She grew close to the man, who assisted her in dealing with her business affairs. Fearing slander (fitna) was inevitable, they decided to legalise the partnership by marriage. Adducing the reason that he would often go and spend much time with her when she needed his help, the man came to the court with the woman to ask permission to marry. The first wife, who was younger than her husband's prospective second wife, who had given her husband children and who had no physical problems, also appeared in court and stated that she agreed with her husband's intention to marry the other woman. Concluding that in asking permission to marry the woman, he had the woman's well-being at heart, the judges decided to acquiesce. Although this rea- 
son is mentioned neither in the 1974 Marriage Law nor in the kompilasi, they believed that their decision was legalised by the practice of ijtihad, which they claim commended this course of action (Nurlaelawati 20I0).

Besides the notion of ijtihad, judges have also often glorified the expression of amr ma'ruf nahy munkar, which is essential for and accepted collectively by Muslims, stressing that they had to involve themselves in the realisation of the notion. For them, giving permission and approving a husband's petition for a polygamous marriage constitutes one of their attempts to forbid evil. They believe that unless they give permission or are lenient about the practice, these husbands would commit zina and fall into sin. Some judges interviewed stated frankly that as members of Muslim society, they have to play a role in applying Islamic law perfectly. In doing so, they seem to be forgetting that the Islamic law that they have to apply has been agreed upon, and that it includes the kompilasi.

\section{Conclusion}

A number of conclusions can be drawn from the above discussion regarding the character of Indonesian Islam, looking specifically at Islamic family law. The first is that, like other Muslim countries, Indonesia has long been motivated to reform Islamic family law in order to bring it into line with present-day conditions and to protect and improve women's legal rights. The second is that legal reform in Indonesia is unique, to some extent, and has its typical foundations in adat and the legal position of authoritative scholars, including traditionalists, modernists and feminist activists. These three groups are strongly attached to their legal positions, to the extent that it is hardly possible to develop a common line regarding reform. Accordingly, with respect to problems that have also been addressed by other Muslim countries, a number of rules that have been introduced by Indonesian state law are very distinct due to the influence of adat and/or the diverse legal opinions of authoritative scholars or legal thinkers. The third is that this uniqueness is not only evident on paper or in written law but also in legal practice. The adherence to fiqh practice in the name of performing ijtihad and actualising the expression of amr maruf nahy munkar seems relevant here. Therefore, there is evidence of ambiguity and dualism both on paper and in practice. 


\section{Notes}

I Permission for such a marriage has to be obtained from the religious court, and this is the one crucial condition for a husband to be allowed to marry more than one wife, if both the parties concerned wish to do so (Art. 3 (2)). A husband can enter into a polygamous marriage only on the grounds that his wife is unable to perform her duties as a wife, because she is suffering from some physical defect or an incurable disease, or when she cannot bear descendants (Art. 4). Furthermore, it stipulates that the marriage can take place if the wife of a husband wishing to resort to polygamy consents, and the husband is financially capable of maintaining co-wives and their descendants. In addition, he has to be prepared to treat the co-wives equally (Art. 5). These regulations are mentioned in Articles 56, 57, and 58 of the kompilasi. The kompilasi insists that a polygamous marriage is only possible when all these conditions are met and reference is made to one of the reasons stated above.

2 Bowen uses this term to describe those attributes of the court system laid down by the 1989 Act in regard to divorce. He also notes that such a position on divorce law reform makes the Indonesian case similar to that of Syria, Morocco and Iraq, but different from that of Tunisia, which has declared divorce out of court to be religiously invalid. See Bowen 200I: Io.

3 One problem is that an aunt will receive a smaller portion than her nephew. When someone dies, leaving behind a daughter (A) and a predeceased son's child (B), A will be given a one-third share, while $B$, as the representative of his father, will be granted two-thirds. Realising that the aunt (A) receives less than her nephew (B), the kompilasi establishes that the share of substitutive heirs must not exceed the portion of the other heirs who have equal positions. Following this additional rule, the portion of B is not two-thirds but one-third, the same portion as A. The remainder of the estate is equally distributed between A and B.

4 My doctoral thesis, entitled 'Modernization, Tradition and Identity: The Kompilasi Hukum Islam and Legal Practice of the Indonesian Religious Courts', was about the legal practices of judges of Indonesian religious courts after the kompilasi was issued. I analysed a hundred decisions to see how these judges applied the kompilasi, and found that in some cases, judges continued to refer to classical Islamic legal doctrines and deviated from the kompilasi. In the case of polygamy, some decisions issued in 2002 and 2003 indicated that judges often approved the petitions for polygamous marriages although the petitioners did not base their request on reasons specified in the kompilasi.

5 Research by PUSKUMHAM (Pusat Studi Hukum, Konstitusi dan Hak Asasi, Centre for the Study of Law, Constitution and Human Rights) revealed that there are some judges who have been sensitive towards gender issues, as can be demonstrated by their attitude when resolving cases of divorce, joint property and polygamy. The research reported that some judges of the courts of Padang, Aceh and Makassar have been very concerned with protecting women's rights. For example, cases of polygamy, where judges required husbands to rethink and where they warned husbands of the effect of their unfairness or unequal treatment of their co-wives, illustrate that gender sensitivity has been widespread in the courts of Aceh and Makassar. Another case from Aceh on divorce, where judges awarded a larger portion of joint property to the wife, as the reason for this divorce was the husband's polygamous marriage, clearly demonstrated that these judges are quite sensitive to gender issues. However, it must be mentioned that greater gender sensitivity was not an instantaneous development but rather resulted from continuous training on the strengthening of gender sensitivity run by a number of branches of the Center for Women's Studies, in cooperation with a number of other foundations. Through this training, the principles of equality, 
justice and fairness mentioned in international treaties and a number of Indonesian laws ratifying them were introduced.

6 However, their conclusion is often mainly due to the fact that judges have cited the kompilasi as the legal reference for their judgements. They neglect the fact that the clear citation of the kompilasi does not always mean that the rules of the kompilasi are being followed in full. If the point is the explicit citation of the kompilasi, I must mention that for their judgements on polygamy discussed above, judges also take the kompilasi as the legal basis. When judges see that the consent of the wife(s) is given and they approve the petition, judges mention the relevant article on the necessity of the wife's (or wives') consent. 


\section{Glossary}

I945 Constitution Indonesian constitution proclaimed on I8 August I945. In force between I945 and I950 and from I959 to date. Pancasila is mentioned in its preamble

\begin{tabular}{|c|c|}
\hline Abangan & Syncretistic or nominal (Javanese) Muslims \\
\hline $\begin{array}{l}\text { Abduh, } \\
\text { Muhammad }\end{array}$ & Religious reformer from Egypt (b. I849, d. I905) \\
\hline Adat & Local traditions/customs \\
\hline Adhan/azan & Call to prayer \\
\hline $\begin{array}{l}\text { al-Afghani, } \\
\text { Jamal al-Din }\end{array}$ & $\begin{array}{l}\text { Religious reformer from Afghanistan (b. I838, } \\
\text { d. I897) }\end{array}$ \\
\hline Ahlu-sunnah & People of the sunnah of the Prophet and the \\
\hline wal-jama‘ah & $\begin{array}{l}\text { Community, those who adhere to Islam in the } \\
\text { right way }\end{array}$ \\
\hline Ahmadiyah & $\begin{array}{l}\text { Religious community originating from Pakistan, } \\
\text { considered heretical by most mainstream Muslims }\end{array}$ \\
\hline Aisyiyah & Women's organisation of the Muhammmadiyah \\
\hline Akhlaq & Morals, ethics \\
\hline Aliran & $\begin{array}{l}\text { Pillar or stream, often used to differentiate } \\
\text { between abangan and santri and between } \\
\text { traditionalist and modernist Muslims }\end{array}$ \\
\hline $\begin{array}{l}\text { Amr ma'ruf nahy } \\
\text { munkar }\end{array}$ & Command what is good and restrain what is evil \\
\hline Ansor & Youth organisation of the Nahdlatul Ulama \\
\hline Aqidah & Faith/belief / / / \\
\hline Asas Tunggal & $\begin{array}{l}\text { Sole basis. The obligation for associations to } \\
\text { declare that Pancasila is their only basic principle }\end{array}$ \\
\hline Aurat & $\begin{array}{l}\text { Parts of the body that should remain covered in } \\
\text { public or when guests are received }\end{array}$ \\
\hline Ayat & Qur'anic verse \\
\hline Barzanji & Poetic text in praise of the Prophet \\
\hline Bedug & Mosque drum \\
\hline Berhala & Idol \\
\hline Bid'a/bidah & Innovation (forbidden by Islam) \\
\hline Bissu & Transgender ritual practitioner in Sulawesi \\
\hline Bughot & Rebel, rebellion \\
\hline
\end{tabular}


Cewek

Dai

Dakwah

Darul Islam

DDII

Detachment 88

Dhikr

DI/TII

Doa/dua

Dukun

Fastabiqul khairat

Fatwa

Fiqh

Fitna(h)

FKASWJ
Lit. young female. Woman who becomes a

feminine partner of a calabai

A person engaged in dakwah

Missionary activity, also among Muslims

Islamic rebellion in Indonesia from I948/9-1965

Dewan Dakwah Islamiyyah Indonesia. Indonesian

Council for Islamic Missionary Activities

Special police anti-terrorism unit

Repetitive chant of part of the Profession of Faith

or other religious phrases

Darul Islam/Tentara Islam Indonesia (Indonesian

Islamic Army)

Supplication, prayer

Diviner, traditional healer

Competing for the betterment of society

Religious legal opinion

Islamic jurisprudence

Slander, division

Forum Komunikasi Ahlu-Sunnah Wal-Jama‘ah,

Communication Forum of the People of the sunna of the Prophet and the Community; mother organisation of Laskar Jihad

FPI

Gamelan

Golkar

Front Pembela Islam, Front of the Defenders of Islam. Paramilitary organisation

Javanese/Balinese traditional music

Golongan Karya (Functional Groups). Government party in the New Order

Guided Democracy Period between I959 and I965

Haba'ib

Male descendant of the Prophet Muhammad

Hadith

Halal

Hal(a)qah

Haram

Hizb al-Tahrir

Hizbullah

HTI

IAIN
Traditions about the words and the deeds of the

Prophet

Legitimate

Lit. circle (after the semi-circle formed by pupils

sitting around their teacher during traditional religious education). Religious study group, usually small

Forbidden

Party of Liberation

Party of God, Forces of God

Hizbut Tahrir Indonesia (Indonesian Party of

Liberation). Radical, fundamentalist Muslim organisation

Institut Agama Islam Negeri (State Institute of Islamic Studies) 


\begin{tabular}{|c|c|}
\hline Ibadah & Worship, ritual observance \\
\hline ICMI & $\begin{array}{l}\text { Ikatan Cendekiawan Muslim se-Indonesia (All- } \\
\text { Indonesian Association of Muslim Intellectuals) }\end{array}$ \\
\hline Idulfitri & Feast at the end of the fasting month \\
\hline Ijab & $\begin{array}{l}\text { The presenting of the bride by her family at a } \\
\text { wedding ceremony }\end{array}$ \\
\hline Ijtihad & $\begin{array}{l}\text { The development of new interpretations and } \\
\text { judgements by the study of the Qur'an and hadith }\end{array}$ \\
\hline \multicolumn{2}{|c|}{ Ikhwan al-Muslimin Mus } \\
\hline Imam & Leader of prayer \\
\hline 'Imamah & Turban \\
\hline Iman & Faith, belief \\
\hline Infaq & Voluntary gift, charity \\
\hline Al-Irsyad & $\begin{array}{l}\text { Reformist Islamic association founded by } \\
\text { Indonesian Muslim Arabs }\end{array}$ \\
\hline Isra Mi'raj & $\begin{array}{l}\text { Journey of the Prophet to Jerusalem and his } \\
\text { ascension to heaven }\end{array}$ \\
\hline Isbal & Ankle-length trousers \\
\hline Istigathah & Large prayer gathering \\
\hline Isya prayer & Evening prayer \\
\hline ITB & $\begin{array}{l}\text { Institut Teknologi Bandung (Bandung Institute of } \\
\text { Technology) }\end{array}$ \\
\hline Jakarta Charter & $\begin{array}{l}\text { Alternative to Pancasila from which it differs by its } \\
\text { mentioning of the obligation of Muslims to follow } \\
\text { Islamic law }\end{array}$ \\
\hline Jalabiya & Long dress, worn by Arab males \\
\hline $\begin{array}{l}\text { Jama'ah (Jemaah) } \\
\text { Islamiyah }\end{array}$ & $\begin{array}{l}\text { Islamic Community. Name of an organisation, } \\
\text { some of whose members have been convicted for } \\
\text { taking part in the Bali bombings and other } \\
\text { terrorist attacks }\end{array}$ \\
\hline JI & Jama'ah Islamiyah \\
\hline Jihad & Struggle, often interpreted as holy war \\
\hline JIL & Liberal (Liberal Islam Network) \\
\hline Jilbab & Headscarf that leaves the face visible \\
\hline Jimat & Amulet \\
\hline Kalam & Word (of God) \\
\hline KAMMI & $\begin{array}{l}\text { Kesatuan Aksi Mahasiswa Muslim Indonesia } \\
\text { (Action Union of Indonesian Muslim Students), an } \\
\text { association of strict Muslim students founded in } \\
\text { March I998 and closely linked to PKS }\end{array}$ \\
\hline Kebatinan & Javanese mysticism \\
\hline Kecapi & Stringed musical instrument \\
\hline Kejawen & Javanese mysticism \\
\hline Kepercayaan & Lit. belief. Javanese mysticism \\
\hline
\end{tabular}




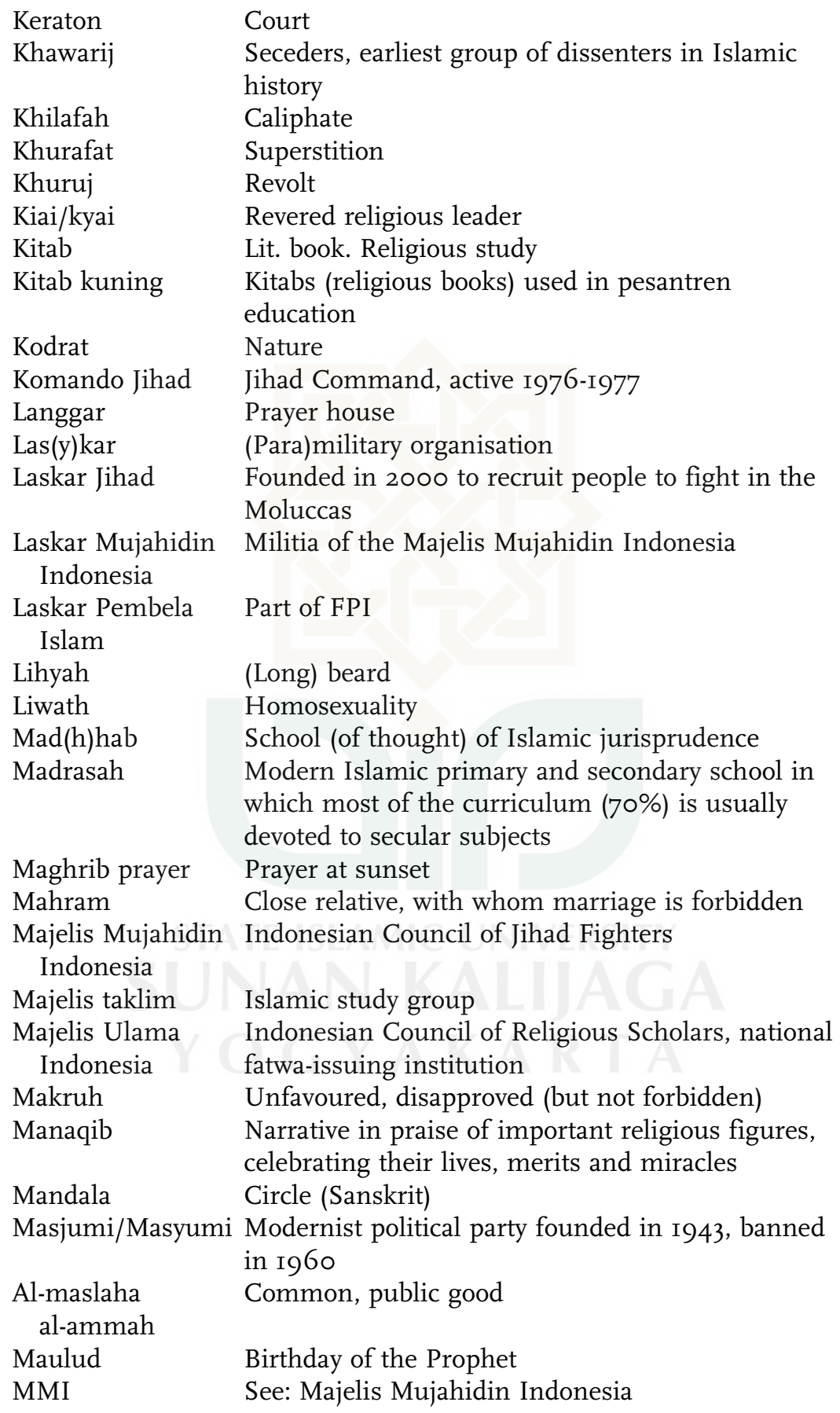


MPR

Mubah

Mudik

Mufti

Muhammadiyah

Muharram

MUI

Mukena

Musafahah

Mushalla

Muslimah

Nahdlatul Ulama

Nahy munkar

Nasyid

Network of

Liberal Islam

New Order

Ngaji

NGO

NII

Al-Nisa

NU

Old Order

PAN

Pancasila

Parmusi

Partai Demokrat

PBB
Majelis Permusyawaratan Rakyat, People's

Consultative Assembly

Indifferent (legal term)

Returning to one's native village (to celebrate Idulfitri)

Person who issues a religious legal opinion

Large modernist socio-religious organisation,

founded in I9I2

First month of the Islamic year

See: Majelis Ulama Indonesia

White garment worn by women when performing prayer

Shaking hands

Small prayer house or room

Muslim woman

The Awakening of Ulama, large traditionalist

socio-religious organisation, which in certain

periods was also a political party; founded in I926

See: Amr ma'ruf nahy munkar

A capella songs

Jaringan Islam Liberal, network of young Muslim

intellectuals founded in $200 \mathrm{I}$

The period between 1965 and 1998

Qu'ran recitation

Non-governmental Organisation

Negara Islam Indonesia, Islamic State of Indonesia

'Women', fourth chapter of the Qur'an

See: Nahdlatul Ulama

The period before I965

Partai Amanat Nasional (National Mandate Party), Islamic political party related to Muhammadiyah.

Founded August i998

Five pillars. The ideological foundation of the Indonesian state. The first one, about religion, speaks of the belief in the One and Only God and does not mention a religion by name

Partai Muslimin Indonesia, founded in I968 under strict government supervision to serve as an alternative to Masjumi

Political party of the current Indonesian President, Susilo Bambang Yudhoyono

Partai Bulan Bintang (Star and Crescent Party), strict Islamic political party, founded July I998

PBUH

Praise be upon Him 
PDI-P

Pengajian

Penghulu

Perda syariah

Persis

Pesantren

PII

PK

PKB

PKI

PKS

PNI

Pondok

PPP

Priyayi

PT

Pulang kampung

Q.

Qabul

Qadi

Qasidah

Q.S.
Partai Demokrasi Indonesia-Perjuangan (Indonesian Democratic Party-Struggle), secular political party headed by Sukarno's daughter Megawati Sukarnoputri

I) Qu'ran recitation

2) Islamic study group, religious lecture Head of religious administration in colonial days Peraturan daerah (local by-law) issued to implement aspects of Islamic law or promote an Islamic way of life

Persatuan Islam (Islamic Union), modernist religious association founded I923

Islamic boarding school

Pelajar Islam Indonesia (Indonesian Islamic Students), banned for its refusal to accept asas tunggal

Partai Keadilan (Justice Party), fundamentalist political party. Founded August I998. See also PKS

Partai Kebangkitan Bangsa (National Awakening Party), political party related to the Nahdlatul Ulama. Founded July i998

Partai Komunis Indonesia (Indonesian

Communist Party). Banned in I966

Partai Keadilan Sejahtera (Prosperous Justice Party). Continuation of PK

Partai Nasional Indonesia (Indonesian National Party). Secular political party, 'Sukarno's party'

I) Pesantren

2) Dormitory in pesantren

Partai Persatuan Pembangunan (United

Development Party). In the New Order, the only

Islamic political party. Radicalised after 1998

Javanese elite

Perseroan terbatas, limited company

Returning to one's native village (to celebrate

Idulfitri)

Qur'an

Acceptance of the bride

Islamic judge

Religious poem

Qur'an Surah, chapter of the Qur'an

Rahma li al-'alamin/rahmatal

lil alamin

Rebab

Blessings for all creation

Stringed instrument 
Rebana

Sadaqa

Salafi/Salafiyya

Santri

Sarekat Islam

Sekolah Islam

Sembahyang

Shafi'i

Shalat

Shalat berjamaah

Shalawat(an)

Shalawat Bad(a)r

Shi'r

S(h)irk

Silatur(r)ahmi

Slametan

STAIN

Sufi

Suharto

Sukarno

Sunna(h)

Surah

Syariah/syariat

Syirik

Tafsir Al-Qur'an

Tahlil

Tahlilan

Takfir

Talqin
Tambourine

Voluntary charity, alms

Muslims who take as their example the society at the time of the Prophet Muhammad and the pious forefathers (al-salaf al-salih), the first generations of Muslims

I) Religious, observant Muslim

2) Pesantren student

Islamic Union, large nationalist association founded in I9I2

Islamic school registered under the Ministry of Education and Culture. Its curriculum follows that of other schools supervised by the ministry

Prayer

Dominant school of Islamic jurisprudence in Southeast Asia

Prayer

Communal prayer

Prayers, verses and songs in praise of the Prophet Muhammad and his family

Song to commemorate the first military victory of Muslim forces at Badar in 624

Poetry genre

Polytheism

Goodwill, meetings to promote good relations

Communal ritual meal

Sekolah Tinggi Agama Islam Negeri (State College of Islamic Studies)

Mystic

(Acting) president of Indonesia from I967 until 1998

President of Indonesia from I945 until I967

Words and deeds of the Prophet

Chapter of the Qur'an

Islamic law

Polytheism

Interpretation, exegesis of the Qur'an

Repeated chanting of the confession of faith

Tahlil ceremony to commemorate a deceased person on the third, seventh, hundredth and thousandth day after his or her death

Declaring another Muslim an unbeliever

Reciting the confession of faith to prepare the deceased for his questioning by the angels of death 
Taqlid

Taqwa

Tarawih

Tarbiyah

Tasawwuf

Taushiyah

Tauhid/Tawhīd

Tuan guru

UIN

Ukhuwah

Ulama

Umma(h)

UNPAD

'Urf

Usroh

Ustad(z)/ ustadh

Wali

Wali Songo

Waria

Wayang

Wetu telu

Wudhu

Zakāh/zaka(t)

Zakat al-fitr

Ziarah

Zina
Following the interpretations of authoritative ulama without questioning them; accepting the interpretations of a school of Islamic jurisprudence Devotion, piety

Special evening prayer during the fasting month Lit. education, used to denote the strict Islam movement at universities

Islamic mysticism (Sufism)

Religious advice

Oneness of God, theology

Religious teacher/leader (used in Lombok, West

Nusa Tenggara)

Universitas Islam Negeri (State Islamic University)

Solidarity

Religious scholar(s)

(Islamic) community

Universitas Padjadjaran (Bandung)

Local traditions/customs

Lit. family. Religious study groups, usually small.

The term is associated with the strict Islam

movement at universities

Religious teacher/leader

I) Saint

2) Closest male relative or guardian of the bride who concludes her marriage contract

The nine saints who spread Islam in Java

Male transvestite

Shadow play

Syncretic form of Islam on the island of Lombok

Ritual ablution before prayer

Mandatory alms

Mandatory almsgiving at the end of the fasting month

Visit, pilgrimage to graves

Adultery 


\section{About the editors and contributors}

Taufik Abdullah is chairman of the Social Science Commission of the Indonesian Academy of Science and Research Professor at the Indonesian Institute of Sciences (Lembaga Ilmu Pengetahuan Indonesia, LIPI), Jakarta.

Azyumardi Azra is Professor of History and Director of Graduate School, Syarif Hidayatullah State Islamic University in Jakarta. He earned his MA in Middle Eastern Studies and his MPhil and PhD degrees in History from Columbia University, New York. He is a member of the Tripartite Forum [governments, UN offices and civil society organisations] for Interfaith Cooperation for Peace, Development and Human Dignity, launched at the UN in New York on 24 March 2006, and of the Council of Faith, World Economic Forum, Davos. Among his publications are The Origins of Islamic Reformism in Southeast Asia (2004) and (as co-editor) Indonesia, Islam and Democracy (2006).

Ahmad Najib Burhani is a PhD candidate in religious studies at the University of California, Santa Barbara, with emphasis on religious minorities with an Islamic origin, such as the Ahmadiyya, Druze, Isma'ili, Yazidi and Baha'i Faith. He is also a researcher at the Indonesian Institute of Sciences (LIPI). Among his publications are Muhammadiyah Jawa (2010), 'Tarekat' tampa Tarekat (2002), Sufisme Kota (200I), and Islam Dinamis (200I).

Jajat Burhanudin is a lecturer at the History Department of the Syarif Hidayatullah State Islamic University in Jakarta. In addition to lecturing, he is engaged in research activities on Islam and Muslim society issues. Until 20II he was Director of the UIN-based Centre for the Study of Islam and Society (Pusat Pengkajian Islam dan Masyarakat, or PPIM), when he was promoted to the position of Director of the University's Research Bureau.

Kees van Dijk is Emeritus Professor of the History of Modern Islam in Indonesia and a former senior researcher at the Royal Institute of Southeast Asian and Caribbean Studies (KITLV) in Leiden. Among his 
publications are The Netherlands Indies and the Great War, 1914-1918 (2007) and (together with Jean Gelman Taylor) Cleanliness and Culture. Indonesian Histories (20II).

Pieternella van Doorn-Harder is Professor of Islamic Studies at Wake Forest University in Winston Salem, North Carolina. She received her $\mathrm{PhD}$ from VU University in Amsterdam. Her research straddles issues concerning women and religion and those concerning minorities, minority cultures and human rights in Muslim countries, and the interreligious encounter between Muslims and Christians. She carried out her main fieldwork in the Middle East and Southeast Asia, specialising in the indigenous Christianity of Egypt and Indonesian Islam. Among the books she has authored is Women Shaping Islam. Indonesian Muslim Women Reading the Qur'an (2006).

Andrée Feillard is a senior researcher at the French Public Centre of Scientific Research (CNRS). She was the representative of the Jakarta bureau of the École Française d'Extrême-Orient. She has specialised in the political history of Indonesia's largest Islamic organisation, the traditionalist Nahdlatul Ulama. Since I999, her attention has turned to the recent emergence of radical Islamist movements (The End of Innocence? Indonesian Islam and the Temptations of Radicalism, co-authored with Rémy Madinier). She has also worked on gender issues in Indonesia since the early i990s.

Robert W. Hefner is Director of the Institute on Culture, Religion, and World Affairs at Boston University and the author or editor of sixteen books on religion and politics, including Muslims and Modernity: Society and Culture Since 1800 (2010).

L. Hilman Latief earned MA degrees from the Center for Religious and Cross Cultural Studies at Gadjah Mada University in Indonesia and from the Department of Comparative Religion at Western Michigan University in 2003 and 2005 respectively. He earned his PhD at Utrecht University in 2012 with a dissertation entitled 'Islamic Charities and Social Activism: Welfare, Dakwah and Politics in Indonesia'. $\mathrm{He}$ is currently a lecturer at the Department of Islamic Economics and Banking, Faculty of Islamic Studies at Universitas Muhammadiyah Yogyakarta (UMY). His publications include Melayani Umat: Filantropi Islam dan Ideologi Kesejahteraan Kaum Modernis (2010).

Euis Nurlaelawati is senior lecturer in Islamic law at the Faculty of Sharia and Law at the Syarif Hidayatullah State Islamic University, and researcher at the Centre for the Study of Law and Human Rights at the 
same university. Her research areas include Islamic (family) law in Indonesia, judicial practices and gender issues. Among her publications are Modernization, Tradition and Identity: The Kompilasi Hukum Islam and Legal Practices in Indonesian Religious Courts (2010) and Demi Keadilan dan Kesetaraan: Dokumentasi Program Sensitivitas Jender Hakim Pengadilan Agama (co-edited with Arskal Salim, 2009).

Nina Nurmila is a senior lecturer at the State Islamic University (UIN) in Bandung, Indonesia. Her first degree was from UIN Bandung (1992), her MA was from Murdoch University (I997) and her PhD was from the University of Melbourne (2007). She was a Fulbright Visiting Researcher at Temple University, Philadelphia (2000-200I), an Endeavour Postdoctoral Fellow at the University of Technology Sydney (2008) and a Fulbright Visiting Scholar of Islamic Studies at the University of Redlands, California (2008-9). She is the author of Women, Islam and Everyday Life: Renegotiating Polygamy in Indonesia (2009, 20II).

Didin Nurul Rosidin studied Qur'anic sciences at IAIN Walisongo in Surakarta, Central Java. From I998 until 2000, he studied for an MA in Islamic Studies at Leiden University. He obtained a PhD in the History of Islam in Indonesia from the same university in 2007. From I998 until 2008, he worked as a lecturer on the History of Islamic Civilisation at the Faculty of Islamic Theology, IAIN Walisongo in Semarang, Central Java. He is currently a lecturer at IAIN Syekh Nurjati Cirebon. In 20II, he was appointed vice dean of the faculty of Islamic Theology and Humanities of IAIN Syekh Nurjati Cirebon.

Dian Maya Safitri is currently an interpreter for the FAO Indonesia Program. She obtained her MA in religious and cultural anthropological studies from the CRCS (Center of Religious and Cross-cultural Studies) at Gadjah Mada University in Indonesia. She held an Asian Graduate Student Fellowship at the Asia Research Institute, National University of Singapore in 20II, and in 2012 she was a visiting fellow of the Training Indonesian Young Leaders Program, Leiden University.

Sunarwoto earned his MA in Islamic studies from Leiden University (2008). He is currently a PhD student at the School of Humanities, Tilburg University, within the framework of the NISIS (Netherlands Interuniversity School for Islamic Studies). The subject of his PhD research is Radio Dakwah in Solo. His academic interests include Qur'anic studies, Islamic history (in Indonesia) and media and Islam.

Asfa Widiyanto obtained his MA from Leiden University and his PhD from the University of Bonn. He is a faculty member at the State Insti- 
tute for Islamic Studies Salatiga in Indonesia. He is currently undertaking postdoctoral research at the Department of Political Science at the University of Marburg and the Department of Islamic Studies at the University of Bamberg (20II-20I3). He recently published Ritual and Leadership in the Subud Brotherhood and the Tariqa Qadiriyya wa Naqshbandiyya (2012).

Syaifudin Zuhri is a lecturer at the Department of Sociology of Religion, Ushuluddin Faculty of Sunan Kalijaga State Islamic University in Yogyakarta, Indonesia. He obtained his MA in Islamic Studies from Leiden University (2009). His research interests include Islamic radicalism and manifestations of Islam in contemporary Indonesia. Among his recent publications are: 'Transnationalising Jamaah Islamiyyah', Al-Jami'ah; Journal of Islamic Studies (2010), 'Changing Paradigm of Indonesian Jihadist Movements: from al-'Aduwu al-Qarīb to al'Aduwu al-Ba'îd', Journal of Indonesian Islam (2010) and 'Discoursing Terrorism through a Contemporary Fatwa: A Study on the View of the Council of Indonesian Ulama', Qanun: Journal of Islamic Law (2010). 


\section{Bibliography}

'Abd al-'Aziz ibn 'Abd Allah ibn 'Abd al-Rahman b. Baz. 1995. Majmu' Fatawa wa Maqalat Mutanawwi'a, Vol. 3. Riyad: Dar al-Qasim li al-Nashr.

Abdillah, Masykuri. 1997. Responses of Indonesian Muslim Intellectuals to the Concept of Democracy (1966-1993). Hamburg: Abera Verlag Meyer \& Co.

Abdullah, Amin. 200I. 'Muhammadiyah's Experience in Promoting Civil Society on the Eve of the $2 \mathrm{I}^{\text {st }}$ Century'. In Mitsuo Nakamura, Sharon Siddique, \& Omar Farouk Bajunid, eds., Islam and Civil Society in Southeast Asia, pp. 43-54. Singapore: ISEAS.

Abdullah, Taufik. 1996. 'The Formation of a New Paradigm? A Sketch on Contemporary'. In Mark R. Woodward (ed.), Toward a New Paradigm: Recent Development in Indonesian Islamic Thought, pp. 47-88. Temple, Arizona: Arizona State University: Program for Southeast Asian Studies.

Abdullah, Taufik. 1971. School and Politics: The Kaum Muda Movement in West Sumatra. Ithaca: Southeast Asian Program, Cornell University.

Abdullah, Taufik. 1998. 'The Clash of Civilizations: A Prognosis of the Future or the Lure of the Past'. Studia Islamika, 5, pp. 77-96.

Abdullah, Taufik. 2009. Indonesia towards Democracy. Singapore: ISEAS.

Abu Zaid, Nasr. 2006. 'The Nexus of Theory and Practice'. In: Mehran Kamrava, The New Voices of Islam. Rethinking Politics and Modernity, pp. I53-I76. Berkeley \& Los Angeles: University of California Press.

Alatas, Alwi. n.d. Kasus Jilbab di Sekolah-sekolah Negeri di Indonesia tahun 1982-1991.

al-Albani. I997. Tahrim Alat al-Tarb aw al-Radd bi al-Wahyiyin wa Aqwal al-A'imatina 'Ala Ibn Hazm wa Muqallidihi al-Mubihina li al-Ma'azif wa al-Ghina wa 'Ala al-Sufiyyin al-Ladhina Ittakhadhu Qirbatan wa Dinan. Maktabat al-Dalil.

al-Albani. 2006. Al-Masa'il al-'Ilmiyya wa al-Fatawa al-Shar'iyya: Fatawa al-Shaikh Nasir alDin al-Albani fi al-Madina wa al-Imarat. Tanta, Egypt: Dar al-Diya'.

Adam, Thomas (ed.). 2004. Philanthropy, Patronage and Civil Society: Experiences from Germany, Great Britain, and North America. Bloomington: Indiana University Press.

Adeney-Risakotta, Bernhard. 2009. 'Religion, Violence and Diversity'. In: Carl Sterkens, Muhammad Machasin \& Frans Wijsen (eds.), Religion, Civil Society and Conflict in Indonesia, pp. 9-27. Berlin \& Zürich: LIT.

el Alami, Dawoud S. 1992. The Marriage Contract in Islamic Law in the Shari'ah and Personal Status Laws of Egypt and Morocco. London: Graham \& Trotan Ltd.

Alfian. 1989. Muhammadiyah: The Political Behavior of a Muslim Modernist Organization under Dutch Colonialism. Yogyakarta: UGM Press.

Ali, Muhamad. 2005. 'The Impact of MUI Fatwas on Freedom of Religion in Indonesia'. The Jakarta Post, 8 August 2005.

Alterman, Jon B. \& Karin von Hippel. 2007. Understanding Islamic Charities. Georgetown: Center for Strategic and International Studies.

Andaya, Leonard. 2000. 'The Bissu. Study of a Third Gender in Indonesia'. In: Barbara Watson Andaya (ed.), Other Pasts. Women, Gender, and History in Early Modern Southeast Asia, pp. 27-46. Honolulu: University of Hawaii Press. 
Anshari, Abu Asma, Abdullah Zaim \& Naibul Umam. 2005. 'Ngetan Ngulon' ketemu Gus Mus: Refleksi $G_{1}$ th KH. A. Mustofa Bisri. Semarang: HMT Foundation.

Anwar, Etin. 2006. Gender and Self in Islam. London: Routledge Publishers.

Anwar, M. Syafi'i. I992. 'Islam, Negara, dan Formasi Sosial dalam Orde Baru: Menguak Dimensi Sosio-Historis Kelahiran dan Perkembangan ICMI'. In Supplement of Ulumul Qu$\operatorname{ran} 3(3)$, pp. I-28.

Anwar, M. Syafi'i. 1995. Pemikiran dan Aksi Islam Indonesia: Sebuah Kajian Politik Tentang Cendekiawan Muslim Orde Baru. Jakarta: Paramadina.

Aqsha, Darul, Dick van der Meij \& Johan Hendrik Meuleman. 1995. Islam in Indonesia: A Survey of Events and Developments from 1988 to March 1993, Seri INIS I6, pp 27-96. Jakarta: INIS.

Armando M., Nina. 2005. Ensiklopedi Islam, vol. 4. PT Ichtiar Baru Van Hoeve.

Arnez, Monika. 20I0. 'Empowering Women through Islam: Fatayat NU between Tradition and Change', Journal of Islamic Studies 2I, pp. 59-88.

Arnold, T.W. I9I3. The Preaching of Islam: A History of the Propagation of the Muslim Faith. London: Constable.

Asad, Talal. I993. Genealogies of Religion. Discipline and Reasons in Christianity and Islam. Baltimore, MD: John Hopkins Press.

Asad, Talal. 2003. Formations of the Secular: Christianity, Islam, Modernity. Cultural Memory in the Present. Stanford, Calif: Stanford University Press.

Asmin, Yudian W. 2002. 'The slogan "Back to the Qur'an and the Sunna": A comparative study of the responses of Hasan Hanafi, Muhammad 'Abid al-Jabiri and Nurcholish Madjid'. PhD dissertation, McGill University.

Aspinall, Edward \& Marcus Mietzner (eds.). 20Io. Problems of Democratisation in Indonesia: Elections, Institutions and Society. Singapore: ISEAS.

Assyaukanie, Luthfi. 2009a. Islam and the Secular State in Indonesia. Singapore: ISEAS Publishing, Institute of Southeast Asian Studies.

Assyaukanie, Luthfi. 2009b. 'Fatwa and Violence in Indonesia', Journal of Religion and Society, II, pp. I-2I.

Atshushi, Ota, Okamoto Masaaki \& Ahmad Suaedy (eds.). 20II. Islam in Contention: Rethinking Islam and the State in Indonesia. Jakarta-Kyoto-Taipei: Wahid Institute-CSEAS-CAPAS.

Auda, Jasser. 2008. Maqasid al-Sharia as Philosophy of Islamic Law: A Systems Approach. London \& Washington: International Institute of Islamic Thought.

Azca, Muhammad Najib. 20II. 'After Jihad: A Biographical Approach to Passionate Politics in Indonesia,' PhD dissertation, Amsterdam University.

Azra, Azyumardi. I994. Jaringan Ulama Timur Tengah dan Kepulauan Nusantara Abad XVII dan XVIII. Melacak Akar-akar Pembaruan Pemikiran Islam di Indonesia. Bandung: Mizan.

Azra, Azyumardi. I999a. Pendidikan Islam di Indonesia: Tradisi Menuju Millenium Baru. Jakarta: Logos.

Azra, Azyumardi. I999b. 'Opposition to Sufism in the East Indies in the Seventeenth and Eighteenth Century', in: Friedrich de Jong \& Bernd Radtke (eds.), Islamic Mysticism Contested: Thirteen Centuries of Controversies and Polemics, pp. 53-58. Leiden: Brill.

Azra, Azyumardi. 2004. The Origins of Islamic Reformism in Southeast Asia. Honolulu: University of Hawaii Press.

Azra, Azyumardi. 2006. Indonesia, Islam and Democracy; Dynamics in a Global Context. Jakarta \& Singapore: ICIP, TAF and Equinoq-Soltice.

Azra, Azyumardi. 2007. Islam in the Indonesian World: An Account of Institutional Development. Jakarta: Mizan.

Azra, Azyumardi. 20I0a. 'An Islamic Perspective of Religious Pluralism in Indonesia: The Impact of Democracy on Conflict Resolution', in KS Nathan (ed.), Religious Pluralism in Democratic Societies. Kuala Lumpur: KAS, MAAS and Select Publishing. 
Azra, Azyumardi. 2orob. 'Cultural Pluralism in Indonesia: Continuous Reinventing of Indonesian Islam in Local, National, and Global Context'. Paper presented at the $10^{\text {th }}$ Annual Conference of Islamic Studies (ACIS), Banjarmasin I-4 November 2010.

Azra, Azyumardi, Kees van Dijk \& Nico Kaptein (eds.). 20I0. Varieties of Religious Authority: Changes and Challenges in 2oth Century Indonesian Islam. Singapore: IIAS \& ISEAS.

Azra, Azyumardi, Afrianty Dina \& Robert Hefner. 2007. 'Pesantren and Madrasa: Muslim Schools and National Ideals in Indonesia, in Schooling Islam'. In Robert W. Hefner \& Muhammad Qasim Zaman (eds.), The Culture and Politics of Muslim Education, pp. I85-I9I. Princeton \& Oxford: Princeton University Press.

Azra, Azyumardi \& Wayne Hudson (contributing eds.). 2008. Islam beyond Conflict: Indonesian Islam and Western Political Theory. Aldershot, Hampshire, UK: Ashgate.

Badran, Margot. I99I. 'Competing agenda: Feminists, Islam and the State in I9th and 2oth century Egypt'. In: Deniz Kandiyoti (ed.), Women, Islam and the State, pp. 20I-236. Basingstoke \& London: Macmillan,.

Badran, Margot. I995. Feminists, Islam, and Nation: Gender and the Making of Modern Egypt. Princeton, NJ: Princeton University Press.

Baktiari, Bahman. 20II. 'Iran: Shari‘a Politics and the Transformation of Islamic Law'. In Robert W. Hefner, ed., Sharia Politics: Islamic Law and Society in the Modern World, pp. I2I-I45. Bloomington: Indiana University Press.

Bamuallim, Chaider S. 2006. Islamic Philanthropy and Social Development in Indonesia. Jakarta: CRSC.

Barfield, Thomas. 20II. 'Afghanistan: The Local and the Global in the Practice of Shari'a.' In Robert W. Hefner, ed., Sharia Politics: Islamic Law and Society in the Modern World, pp. I79-206. Bloomington: Indiana University Press.

Bayat, Asef. 1998. 'Revolution without Movement, Movement without Revolution: Comparing Islamic Activism in Iran and Egypt', Comparative Studies of Society in History, 40, pp. I36-I69.

Beatty, Andrew. 1999. Varieties of Javanese Religion: An Anthropological Account. Cambridge: Cambridge University Press.

Beken, Munir. 2004. 'Music'. In: Richard C. Martin (ed.), Encyclopedia of Islam and the Muslim World, vol. 2, p.493. New York: MacMillan Reference USA.

Benthall, Jonathan \& Jérôme Bellion-Jourdan. 2003. The Charitable Crescent: Politics of Aid in the Muslim World. London and New York: I.B. Tauris.

Berger, Peter L. 2007. 'Foreword': In: Nancy T. Ammerman (ed.), Everyday religion. Observing modern religious lives, pp. v-viii. Oxford, NY: Oxford University Press.

Berkey, Jonathan. 1992. The Transmission of Knowledge in Medieval Cairo: A Social History of Islamic Education. Princeton: Princeton University Press.

Binder, Leonard. 1988. Islamic Binder: A Critique of Development Ideologies. Chicago \& London: University of Chicago.

Bisri, A. Mustofa. 2009. 'Perbedaan Fatwa, Wacana dan Vonis', Sinergi Indonesia, 7 (I), pp. II-I2.

Blackburn, Susan. 2004. Women and the State in Modern Indonesia. Cambridge: Cambridge University Press.

Blackwood, Evelyn. 2000. Webs of Power: Women, Kin, and Community in a Sumatran Village. Lanham: Rowman \& Littlefield.

Blackwood, Evelyn. 2005a. 'Wedding Bell Blues: Marriage, Missing Men, and Matrifocal Follies', American Ethnologist 32 (I), pp. 3-I9.

Blackwood, Evelyn. 2005b. 'Gender Transgression in Colonial and Postcolonial Indonesia', The Journal of Asian Studies 64 (4), pp. 849-879.

Blackwood, Evelyn. 2005c. 'Transnational Sexualities in One Place. Indonesian Readings', Gender and Society I9 (2), pp. 22I-242. 
Boellstorff, Tom. 2005. The Gay Archipelago. Sexuality and Nation in Indonesia. Oxford \& Princeton, NJ: Princeton University Press.

Boellstorff, Tom. 2004. 'Playing Back the Nation. Waria, Indonesian Transvestites', Cultural Anthropology i9 (2), pp. I59-I95.

Boland, B.J. I97I. The Struggle of Islam in Modern Indonesia. The Hague: Martinus Nijhoff.

Bourdieu, Pierre. I977. Outline of a Theory of Practice. Cambridge: Cambridge University Press.

Bourdieu, Pierre. I990. The Logic of Practice. Stanford, CA: Stanford University Press.

Bowen, John R. I993. Muslims through Discourse: Religion and Ritual in Gayo Society. Princeton: Princeton University Press.

Bowen, John R. 200I. Shari'a, State, and Social Norms in France and Indonesia. Leiden: Institute of the Study of Islam in the Muslim World (ISIM).

Bowen, John R. 2003. Islam, Law, and Equality in Indonesia: Anthropology of Public Reasoning. Cambridge [etc.]: Cambridge University Press.

Bowen, John R. 2008. Religions in Practice: An Approach to the Anthropology of Religion. 4th Edition, Boston: Pearson Education, Inc.

Braune, W. I986. ' 'Abd al-Kadir al-Djilani'. In: Encyclopaedia of Islam, 2nd ed., vol. I, pp. 6970. Leiden: E.J. Brill.

Breet, Michael. 2003. De Oost-Indische voyagie van Wouter Schouten. Zutphen: Walburg Pers.

Brenner, Suzanne. I996. 'Reconstructing Self and Society. Javanese Muslim Women and “the Veil”', American Ethnologies 23 (4), pp. 673-697.

Brenner, Suzanne A. I998. The Domestication of Desire: Women, Wealth, and Modernity in Java. Princeton, NJ: Princeton University Press.

Brenner, Suzanne. 2005. 'Islam and Gender Politics in Late N.O. Indonesia'. In Andrew C. Willford \& Kenneth M. George (eds.), Spirited Politics: Religion and Public Life in Contemporary SEA, pp. II3-II5. SEAP, Cornell,.

Brown, Nathan. 20II. 'Egypt: Cacophony and Consensus in the Twenty-first Century'. In Robert W. Hefner, ed., Sharia Politics: Islamic Law and Society in the Modern World, pp. 94I20. Bloomington: Indiana University Press.

Bruinessen, Martin van. I990. 'Global and Local in Indonesian Islam', Southeast Asian Studies, 37 (2), pp. 46-63.

Bruinessen, Martin van. I994. 'Pesantren and Kitab Kuning: Maintenance and Continuation of a Tradition of Religious Learning'. In Wolfgang Marschall, ed., Texts from the Islands: Oral and Written Traditions of Indonesia and the Malaya World, pp. I2I-45. Bern: University of Bern Press.

Bruinessen, Martin van. I995a. Kitab kuning, pesantren, dan tarekat. Tradisi-tradisi Islam di Indonesia. Bandung: Mizan.

Bruinessen, Martin van. I995b. 'Shari'a court, tarekat and pesantren: Religious Institutions in the Banten Sultanate' Archipel 50, pp. I65-200.

Bruinessen, Martin van. I999. 'Global and Local in Indonesian Islam', Southeast Asian Studies 37 (2), pp. I58-I75.

Bruinessen, Martin van. 2002. 'Genealogies of Islamic Radicalism in Post Soeharto Indonesia', Southeast Asia Research, Io (2), pp. II7-54.

Bruinessen, Martin van. 2006. 'Nurcholish Madjid: Indonesian Muslim Intellectual', ISIM Review I7/Spring, pp. 22-23.

Bruinessen, Martin van. 2007. 'Development and Islamic Charities', ISIM Review, 20 (Autumn 2007), p. 5 .

Bruinessen, Martin van. 2009. 'Genealogies of Islamic Radicalism in Post Suharto Indonesia'. In: Joseph Chinyong \& Nadirsyah Hosen (eds.), Islam in Southeast Asia: Critical Concepts in Islamic Studies, pp. 35-66. London: Routledge. 
Bruinessen, Martin van. 20II. 'What happened to the Smiling Face of Indonesian Islam? Muslim Intellectualism and the conservative turn in post-Suharto Indonesia'. Working paper, pp. I-45. Singapore: S. Rajaratnam School of International Studies.

Bubalo, Anthony, Greg Fealy \& Whit Mason. 2008. Zealous Democrats: Islamism and Democracy in Egypt, Indonesia and Turkey. Double Bay, New South Wales: Lowy Institute.

Bulliet, Richard W. I994. Islam: The View from the Edge. New York: Columbia University Press.

Burhanudin, Jajat. 2006. 'Kerajaan-Oriented Islam: The Experience of pre-Colonial Indonesia', Studia Islamika I3 (I), pp. 33-66.

Burhanudin, Jajat. 2007. 'Islamic Knowledge, Authority and Political Power: The Ulama in Colonial Indonesia'. PhD thesis, Leiden University.

Burr, J. Millard \& Robert O. Collins. 2006. Alms for Jihad: Charity and Terrorism in the Islamic World. Cambridge: Cambridge University Press.

Bush, Robin. 2009. Nahdlatul Ulama and the Struggle for Power within Islam and Politics in Indonesia. Singapore: ISEAS Press.

Butler, Judith. I990. Gender Trouble. Feminism and the Subversion of Identity. New York: Routledge.

Butler, Judith. I997. The Psychic Life of Power. Theories in Subjection. Stanford, CA: Stanford University Press.

Cammack, Mark. I997. 'Indonesia's I989 Religious Judicature Act: Islamization of Indonesia or Indonesianization of Islam', Indonesia 63, pp. I43-I68.

Cammack, Mark. I999. 'Inching towards Equality: Recent Developments in Indonesian Inheritance Law', WUML Dossier (22 November).

Candraningrum, Dewi. 20I0. 'Perda Sharia and the Indonesian Women's Critical Perspectives', pp. I-I2, www.asienhaus.de/public/archiv/PaperPERDASHARIA.pdf, accessed on 3I July 20 II.

Carroll, Lucy. I998. 'Orphaned Grandchildren in Islamic Law of Succession', Islamic Law and Society, 5 (I), pp. 409-447.

Casanova, J. I994. Public Religions in the Modern World. Chicago: Chicago University Press.

Challand, Benoît. 2008. 'A Nahda of Charitable Organizations? Health Service Provision and the Politics of Aid in Palestine', International Journal of Middle East Studies, 40, pp. 22747.

Chamberlain, Michael. 1994. Knowledge and Social Practice in Medieval Damascus, 1190-1350. Cambridge Studies in Islamic Civilization. Cambridge: Cambridge University Press.

Clark, Janine A. 2004. Islam, Charity, and Activism: Middle Class Networks and Social Welfare in Egypt, Jordan and Yemen. Bloomington \& Indianapolis: Indiana University Press.

Colombijn, Freek \& J. Thomas Lindblad (eds.). 2002. The Roots of Violence in Indonesia. Leiden: KITLV.

Connolly, William E. 2005. Pluralism. Duke University Press.

Crompton, Louis. I98I. 'The Myth of Lesbian Impunity. Capital Laws from I270 to I79I', Journal of Homosexuality 6 (I/2), pp. II-25.

Crouch, Harold. 20I0. Political Reform in Indonesia after Soeharto. Singapore: ISEAS.

Damanik, Ali Said. 2002. Fenomena Partai Keadilan: Transformasi 20 Tahun Gerakan Tarbiyah di Indonesia. Bandung: Mizan.

Daniels, Timothy P. 2009. Islamic Spectrum in Java. Burlington: Asghate.

Davies, Sharyn Graham. 2007. Challenging Gender Norms. Five Genders among Bugis in Indonesia. Belmont, CA: Thomson Wadsworth.

Deeb, Lara. 2009. 'Piety Politics and the Role of a Transnational Feminist Analysis', Journal of the Royal Anthropological Institute 15, pp. II2-I26. 
Departemen Agama. I992. Compilation of Islamic Law, Marriage Law No. I/1974 and Islamic Judicature Law of 1989. Jakarta: DEPAG.

Derichs, Claudia \& Andrea Fleschenberg (eds.). 20I0. Religious Fundamentalisms and their Gendered Impacts in Asia. Berlin: Friedrich-Ebert-Stiftung.

Dharmaputera, Eka. I994. 'Institute Dian/Intefidei: Sebuah Sumbangan Dialog' . In: Th. Sumartana et al. (eds.), Dialog: Kritik dan Identitas Agama, pp. 249-56. Yogyakarta: Pustaka Pelajar.

Dhofier, Zamakhsari. 1999 [orig. 1982]. The Pesantren Tradition: The Role of the Kyai in the Maintenance of Traditional Islam in Java. Tempe: Program for Southeast Asian Studies, Arizona State University.

Dick, H.W. I985. 'The Rise of a Middle Class and the Changing concept of Equity in Indonesia: An Interpretation', Indonesia, 39, pp. 7I-92.

Dick, H.W. I990. 'Further Reflection on the Middle Class'. In: Richard Tanter and Kenneth Young (eds.), The Politics of Middle Class, pp. 64-5. Clayton: Centre of Southeast Asian Studies, Monash University.

Dijk, C. van. I98I. Rebellion Under the Banner of Islam: The Darul Islam in Indonesia. Verhandelingen van Het KITLV No. 94. The Hague: Martinus Nijhoff.

Dijk, Kees van. I997. 'Sarong, jubbah and trousers. Appearances as a means of

distinction and discrimination'. In: H. Schulte Nordholt (ed.) Outward Appearances: Dressing State and Society in Indonesia, pp. 39-83. KITLV proceedings 4.

Dijk, Kees van. 2007. 'The Changing Contour of Mosques'. In: P.J.M. Nas (ed.) The Past in the Present. Architecture in Indonesia, pp. 45-66. Rotterdam and Leiden: NAi Publishers and KITLV Press.

Doorn-Harder, Pieternella van. 2006. Women shaping Islam, Reading the Qur'an in Indonesia. Urbana \& Chicago: University of Illinois Press.

Doorn-Harder, Pieternella van. 2007. 'Re-considering Authority: Indonesian Fiqh Texts about Women'. In: R. Michael Feener \& Mark Cammack, Islamic Law in Modern Indonesia: Ideas and Institutions, pp. 27-43. Cambridge, MA: Harvard University Press.

Doorn-Harder, Pieternella van. 2008. 'Controlling the Body: Muslim Feminists Debating Women's Rights in Indonesia’, Religion Compass, 2 (6), pp. IO2I-I043. Oxford, UK: Blackwell Publishing Ltd.

Drewes, G.W. J. I969. The Admonitions of Seh Bari. The Hague: Martinus Nijhoff.

Eck, Diana L. 2007a. 'American Religious Pluralism: Civic and Theological Discourse'. In: Thomas Banchoff (ed.) Democracy and the New Religious Pluralism, pp. 243-270. Oxford: Oxford University Press.

Eck, Diana L. 2007b. 'Prospects for Pluralism: Voice and Vision in the Study of Religion'. Journal of the American Academy of Religion, 75 (4), pp. 743-776.

Editors. 2004. 'al-Busiri'. In: Encyclopaedia of Islam, 2nd ed. Vol, I2, Supplement, pp. I58I59. Leiden: Brill.

Edwards, Bob \& Michael W. Foley. 20oI. 'Civil Society and Social Capital: A Primer'. In: Bob Edwards, Michael W. Foley, \& Mario Diani (eds.), Beyond Tocqueville: Civil Society and the Social Capital Debate in Comparative Perspective, pp. I-I4. Hanover: University Press of New England.

Effendi, Bahtiar. I994. 'Islam and the State: The Transformation of Islamic Political Ideas and Practices in Indonesia.' PhD Dissertation, Ohio University.

Effendi, Bahtiar. I995. 'Islam and the State of Indonesia', Studia Islamika, 2 (2), pp 97-I22.

Effendy, Bahtiar. 200I. Teologi Baru Politik Islam: Pertautan Agama, Negara dan Demokrasi. Yogyakarta: Galang Press.

Effendy, Bahtiar \& Soetrisno Hadi (eds.). 2007. Agama dan Radikalisme di Indonesia, Jakarta: Nuqtah. 
Eickelman, Dale \& James Piscatori. 200I. 'What is Muslim Politics'. In: Dale Eickelman \& James Piscatori (eds.), Muslim Politics. Princeton, New Jersey: Princeton University Press.

Eickelman, Dale \& Jon W. Anderson. 2003. 'Redefining Muslim Publics'. In: Dale Eickelman \& Jon Anderson (eds.), New Media in the Muslim World: The Emerging Public Sphere, pp. II8. 2nd ed. Bloomington \& Indianapolis: Indiana University Press.

Emmerson, Donald K. I98I 'Islam in Modern Indonesia: Political Impasse, Cultural Opportunity'. In: Philip H. Stoddard, et al. (eds.), Change and the Muslim World, pp. I59-I69. Syracuse: Syracuse University Press.

Esposito, John L. I982. Women in Muslim Family Law. New York: Syracuse University Press. Esposito, John L. 200I. Women in Muslim Family Law. New York: Syracuse University Press.

Esposito, John L. \& Dalia Mogahed. 2007. Who Speaks for Islam: What A Billion Muslims Really Think. New York: Gallup Press.

Evans, Peter, ed. I997. State-Society Synergy: Government and Social Capital in Development. Berkeley, CA: University of California International and Area Studies Digital Collection, Research Series \#94.

Faqihuddin, Abdul Kodir. 2005. Memilih Monogami. Pembacaan Atas Al-Qur'an dan Hadits Nabi. Yogyakarta, LKiS.

al Faruqi, Lois Ibsen. I985. 'Music, Musicians and Muslim Law', Asian Music, I7 (I), pp. 336.

Fealy, Greg \& Anthony Bubalo. 2007. Jejak Kafilah: Pengaruh Radikalisme Timur Tengah di Indonesia. Bandung: Mizan.

Federspiel, Howard M. I970. Pesatuan Islam: Islamic Reform in Twentieth Century Indonesia. Ithaca and New York: Modern Indonesia Project, Cornell University.

Federspiel, Howard M. 200I. Islam and Ideology in the Emerging Indonesia State: The Persatuan Islam (PERSIS), 1923 to 1957. Leiden: Brill.

Feener, R. Michael. 2002. 'Indonesian Movements for the Creation of a National Madhhab', Islamic Law and Society, 9 (I), pp. 83-II5.

Feener, R. Michael. 2007. Muslim Legal Thought in Modern Indonesia. Cambridge: Cambridge University Press.

Feillard, Andrée. I995. Islam et Armée dans l'Indonésie Contemporaine. Paris: L'Harmattan.

Feillard, Andrée. I997. 'Indonesia's Emerging Muslim Feminism: Women Leaders on Equality, Inheritance and Other Gender Issues'. In: Studia Islamika, 4 (I), pp. 83-III.

Feillard, Andrée. I999. 'The Veil and Polygamy: Current Debates on Women and Islam in Indonesia'. Moussons I2, pp. 5-28.

Feillard, Andrée. 2008. 'Islamisme et démocratie en Indonésie : quand la tradition se rapproche de la cause des femmes'. Archipel 75, pp. 199-230.

Feillard, Andrée \& Lies Marcoes-Natsir. I998. 'Female circumcision in Indonesia: To Islamize in ceremony or secrecy', Archipel 56, pp. 337-367.

Feillard Andrée \& Rémy Madinier. 20II. The end of Innocence, Indonesian Islam and the Temptations of Radicalism. Singapore: NUS Press.

Feith, Herbert. I962. The Decline of Constitutional Democracy in Indonesia. New York: Cornell University Press.

Foucault, Michel. I997. 'Ethics, Subjectivity, and Truth, Essential Works of Foucault, I954I984’. In: Paul Rabinow (ed.), Essential Works of Foucault, Vol. I, pp. 8I-85. New York: The New Press.

Foucault, Michel. I990a. An Introduction. Vol. 1 of the History of Sexuality, Robert Hurley (trans.). New York: Vintage Books.

Foucault, Michel. I990b. The Use of Pleasure. Vol. 2 of the History of Sexuality, Robert Hurley (trans.). New York: Vintage Books.

Foucault, Michel. 1988. The Care of the Self. Vol. 3 of the History of Sexuality, Robert Hurley (trans.). New York: Vintage Books. 
Franke, Edith. 2006. 'Zwischen Integration und Konflikt: Religiöse Pluralität in Indonesia'. In: Edith Franke \& Michael Pye (eds.), Religionen Nebeneinander: Modelle religiöser Vielfalt in Ost- und Südostasien, pp. 6I-82. Berlin \& Zürich: LIT.

Franke, Edith and Michael Pye. 2006. 'Religionen Nebeneinander: Religionswissenschaftliche Perspektive auf Modelle religiöser Pluralität'. In: Edith Franke \& Michael Pye (eds.), Religionen Nebeneinander: Modelle religiöser Vielfalt in Ost- und Südostasien, pp. 9-I6. Berlin \& Zürich: LIT.

Franke, Patrick. 2002. 'Rückkehr des Heiligen Krieges? Dschihad-Theorien im modernen Islam'. In: André Stanisavljevic \& Ralf Zwengel (eds.): Religion und Gewalt. Der Islam nach dem 11. September, pp. 47-68. Potsdam: Mostar Friedensprojekte e.V.

Fraser, Colin \& Sonia Restrepo Estrada. 200I. Community Radio Handbook. Bangkok: UNESCO Bangkok and Regional Bureau for Education in Asia and the Pacific.

Gade, Anna. 2002. 'Taste, Talent, and the Problem of Internalization. A Quranic Study in Religious Musicality from Southeast Asia, History of Religions (4I) 4, pp. 328-368.

Gaffney, Patrick D. 1994. The Prophet's Pulpit: Islamic Preaching in Contemporary Egypt. Berkeley: University of California Press.

Geertz, Clifford. I96oa. Religion of Java. London: Free Press of Glencoe.

Geertz, Clifford. I96ob. 'The Javanese Kijaji: The Changing Role of a Cultural Broker', Comparative Studies in Society and History, 2 (2) (Jan. I960), pp. 228-249.

Geertz, Clifford. 1963. Agricultural Involution: The Processes of Ecological Change in Indonesia. Berkeley, CA: University of California Press.

Geertz, Clifford. 1964. The Religion of Java. Glencoe, IL: Free Press.

Geertz, Clifford. 1965. The Social History of an Indonesian Town. Cambridge, Mass: MIT Press.

Geertz, Clifford. 1968. Islam Observed. Religious Development in Morocco and Indonesia. Chicago and London: The University of Chicago Press.

Geertz, Clifford. I97I. Islam Observed: Religious Development in Morocco and Indonesia. University of Chicago Press.

Geertz, Clifford. 1976 (1960). The Religion of Java. Chicago \& London: The University of Chicago Press.

Geertz, Hildred. 196r. The Javanese Family: A Study of Kinship and Socialization. USA: The Free Press of Glencoe.

Geertz, Hildred \& Clifford Geertz. 1975. Kinship in Bali. Chicago, University of Chicago Press.

Gellner, Ernest. 198I. Muslim Society. Cambridge studies in social anthropology, 32. Cambridge: Cambridge University Press.

Ghazali, Abd Moqsith (ed.). 2005. Ijtihad Islam Liberal. Jakarta: Jaringan Islam Liberal.

Habermas, Jürgen. I99I. The Structural Transformation of the Public Sphere. Cambridge, Massachusetts: The MIT Press.

Habibie, Bacharuddin Jusuf. 2006. Detik-Detik yang Menentukan: Jalan Panjang Indonesia Menuju Demokrasi, pp. 69-83. Jakarta: THC Mandiri.

Hadikusuma, Hilman. I980. Hukum Waris Adat. Bandung: Penerbit Alumni.

Hadikusuma, Hilman. I99I. Hukum Waris Indonesia Menurut Perundangan, Hukum Adat, Hukum Agama Hindu, Islam. Bandung: P.T. Citra Adtya Bakti.

Hallaq, Wael B. 2009. An Introduction to Islamic Law. Cambridge: Cambridge University Press.

Hamidi, Jazim \& Asyhari Abta. 2005 . Syiiran Kiai-kiai. Yogyakarta: Pustaka Pesantren.

Hara, Abubakar Eby. 20I0. 'Pancasila and the Perda Syariah Debates in the Post-Suharto Era: Toward a New Political Consensus'. In: Ota Atsushi, Okamoto Masaaki \& Ahmad 
Suaedy (eds.), Islam in Contention: Rethinking Islam and State in Indonesia, pp. 35-76. Jakarta, Kyoto \& Taipei: Wahid Institute-CSEAS-CAPAS.

Harahap, M. Yahya. I988. Praktek Hukum Waris tidak Pantas Membuat Generalisasi‘. In: Saimima, Polemik Reaktualisasi Ajaran Islam, pp I24-I48. Jakarta: Pustaka Panjimas.

Harriss, John. 2006. 'Middle Class Activism and the Politics of the Informal Working Class: A Perspective on Class Relations and Civil Society in Indian Cities', Critical Asian Studies, 38 (4), pp. 445-65.

Harun, Shaleh \& Abdul Munir Mulkhan. 1986. Latar Belakang Ummat Islam Menerima Pancasila Sebagai Asas Tunggal: Sebuah Kajian Informatif Pandangan NU-Muhammadiyah. Yogyakarta: Aquarius.

Hasan, Muhammad Kamal. I980. Muslim Intellectual Responses to 'New Order' Modernization in Indonesia. Kuala Lumpur: Dewan Bahasa dan Pustaka.

Hasan, Noorhaidi. 2002. 'Faith and Politics: The Rise of the Laskar Jihad in the Era of Transition in Indonesia', Indonesia, 73 (April 2002), pp. I45-69.

Hasan, Noorhaidi. 2005. 'Laskar Jihad Islam, Militancy and the Quest for Identity in PostNew Order Indonesia', PhD dissertation submitted to Utrecht University, The Netherlands.

Hasan, Noorhaidi. 2006. Laskar Jihad: Islam, Militancy and the Quest for Identity in Post-new Order Indonesia. Ithaca (NY): Cornell University.

Hasan, Noorhaidi. 2008. 'The Salafi Madrasas of Indonesia'. In: Farish A. Noor, Yoginder Sikand \& Martin van Bruinessen (eds.), The Madrasa in Asia: Political Activism and Transnational Linkages, pp. 247-274. Amsterdam: ISIM/Amsterdam University Press.

Hasbullah, Moeflich. 2000. 'Cultural presentation of the Muslim Middle Class in Contemporary Indonesia’, Studia Islamika, 7 (2), pp. I-58.

Hatta, Mohammad. I960. Demokrasi Kita. Djakarta: Pandji Masyarakat.

Hazairin. I963. Hukum Islam dan Masyarakat. Jakarta: Tintamas.

Hefner, Robert W. I985. Hindu Javanese: Tengger Tradition and Islam. Princeton: Princeton University Press.

Hefner, Robert W. I993. 'Islam, State, and Civil Society: ICMI and the struggle for the Indonesian Middle Class', Indonesia, 56, pp. I-35.

Hefner, Robert W. I997a. 'A Gentle Blend of Islam and Adat'. In: Eric Oey (ed.), Java, pp. 66-69. Singapore: Periplus Editions.

Hefner, Robert W. I997b. 'Print Islam', Indonesia, 64, pp. 77-I03.

Hefner, Robert W. I998. 'Markets and Justice for Muslims Indonesians'. In: Robert W. Hefner (ed.), Market Culture: Society and Values in the New Asian Capitalism, pp. 224-50. Singapore: ISEAS.

Hefner, Robert W. 2000. Civil Islam: Muslims and Democratization in Indonesia. Princeton: Princeton University Press.

Hefner, Robert W. 200Ia. 'Introduction: Multiculturalism and Citizenship in Malaysia, Singapore, and Indonesia'. In Robert W. Hefner, ed., The Politics of Multiculturalism: Pluralism and Citizenship in Malaysia, Singapore, and Indonesia, pp. I-58. Honolulu: University of Hawai'i Press.

Hefner, Robert W. 20orb. 'Where Have All the Abangan Gone? Religionization and the Decline of Non-standard Islam in Contemporary Indonesia'. In: Michel Picard \& Rémy Madinier (eds.), The politics of Religion in Indonesia. Syncretism, orthodoxy, and religious Contention in Java and Bali, pp. 7I-9I. London \& New York: Routledge.

Hefner, Robert W. 200Ic. 'Public Islam and the Problem of Democratization', Sociology of Religion, 62 (4), pp. 49I-5I4.

Hefner, Robert W. 2005a. 'Muslim Democrats and Islamist Violence in Post-Soeharto Indonesia'. In: Robert W. Hefner (ed.), Remaking Muslim Politics: Pluralism, Contestation, Democratization, pp. 273-30I. Princeton: Princeton University Press. 
Hefner, Robert W. 2005b . 'Introduction: Modernity and the Remaking of Muslim Politics'. In: Robert W. Hefner (ed.), Remaking Muslim Politics, pp. I-37. Princeton: Princeton University Press.

Hefner, Robert W. 2007. 'Introduction: The Culture, Politics, and Future of Muslim Education'. In: Robert W. Hefner \& Muhammad Qasim Zaman (eds.), Schooling Islam: The Culture and Politics of Modern Muslim Education, pp. I-39. Princeton: Princeton University Press.

Hefner, Robert W. (ed). 2009. Making Modern Muslims: The Politics of Islamic Education in Southeast Asia. Honolulu: University of Hawai'i Press.

Hefner, Robert W. 20IIa. 'Where have all the abangan gone? Religionization and the decline of non-standard Islam in contemporary Indonesia'. In Michel Picard \& Remy Madinier, eds., The Politics of Religion in Indonesia: Syncretism, Orthodoxy, and Religious Contention in Java and Bali, pp. 7I-9I. London: Routledge.

Hefner, Robert W. 2orrb. 'Human Rights in Islam: The Indonesian Case in Comparative Perspective'. In: Thomas Banchoff \& Robert Wuthnow (eds.), Religion and the Global Politics of Human Rights, pp. 39-69. Oxford: Oxford University Press.

Hefner, Robert W. \& Muhammed Qasim Zaman (eds.). 2007. Schooling Islam, The Culture and Politics of Muslim Education. Princeton \& Oxford: Princeton University Press.

Heryanto, Ariel. 20II. 'Upgrading Piety and Pleasure: the New Middle Class and Islam in Indonesian Popular Culture'. In: Andrew N. Weintraub (ed.), Islam and Popular Culture in Indonesia and Malaysia, pp. 6o-82. London: Routledge.

Hick, John. I987. 'Religious Pluralism', The Encyclopaedia of Religion, vol. I2, pp. 331-333.

Hidayat, Komarudin. 2009. 'Radikalisme Menyusup ke SMU', www.uinjkt.ac.id.

Hilmy, Masdar. 2010. Islamism and Democracy in Indonesia: Piety and Pragmatism. Singapore: ISEAS Series on Islam.

Hirschkind, Charles. 200I. 'The Ethics of Listening. Cassette Sermons in Contemporary Egypt', American Ethnologies 28 (3), pp. 623-649.

Hirschman, Charles \& Jennifer Edwards. 2006. 'Social change in Southeast Asia'. Online. Available at www.soc.washington.edu/users/charles/pubs/8\%20Hirschman\%2oand\% 20Edwards\%20final_text.pdf (accessed 24 April 2006).

Hodgson, Marshall. 1974. The Venture of Islam: Conscience and History in a World Civilization. Three Vols. Chicago: University of Chicago Press.

Hoesterey, James B. 2008. 'Marketing Morality: The Rise, Fall, and Rebranding of Aa Gym'. In: Greg Fealy \& Sally White (eds.), Expressing Islam: Religious Life and Politics in Indonesia, pp. 95-II2. Singapore: ISEAS Press.

Hooker, M. B. 2003. Indonesian Islam: Social Change through Contemporary Fatāwā. Honolulu: University of Hawaii Press.

Hornby, A.S. 20I0. Oxford Advanced Learner's Dictionary. 8th edition. Oxford, NY: Oxford University Press.

Howel, Julia Day. 2005. 'Muslims, the New Age and Marginal Religions in Indonesia', Social Compass, 52 (4), pp. 473-493.

Huff, Toby. 2003. The Rise of Early Modern Science: Islam, China, and The West, $2^{\text {nd }}$ ed. Cambridge: Cambridge University Press, 2003.

Husin, Asna. 1998. 'Philosophical and Sociological Aspects of Da'wah: A Study of Dewan Dakwah Islamiyah Indonesia (Islamic Indonesian Council on Islamic Mission'. Unpublished PhD dissertation, Columbia University.

Ibrahim, Barbara Lethem \& Dina H. Sherif. 2008. From Charity to Social Change: Trends in Arab Philanthropy. Cairo \& New York: The American University Press.

ICG. 2002. 'Al-Qaeda in Southeast Asia: The Case of the 'Ngruki Network' in Indonesia'. Jakarta and Brussels: ICG Asia Report, August 8. 
ICG. 2005. 'Recycling Militants in Indonesia: Darul Islam and the Australian Embassy Bombing'. Jakarta and Brussels: Asia Report No. 92, February 2005.

ICG. 2008. 'Indonesia: Implications of the Ahmadiyah Decree'. Jakarta and Brussels: Asia Briefing No. 78 .

Ichwan, Moch. Nur. 2005. 'Ulama', State and Politics: Majelis Ulama Indonesia after Suharto', Islamic Law and Society, I2 (I), pp. 45-72.

Ikhsan, Muhammad. n.d. Gerakan Salafi Modern di Indonesia: Sebuah Upaya Membedah Akar Pertumbuhan dan Ide-ide Substansialnya.

Ismail, Noor Huda and Carl Ungerer. 2009. 'Jemaah Islamiyah: A Renewed Struggle?', Australian Strategic Policy Institute, I6 July.

Ismail, Nurjannah. 2003. Perempuan dalam Pasungan. Bias Laki-laki dalam Penafsiran. Yogyakarta: LKiS.

Jabali, Fuad \& Jamhari (eds.). 2002. IAIN dan Modernisasi Islam di Indonesia. Jakarta: Logos Wacana Ilmu.

al-Jābirī, Muhammad 'Ābid. I999. Arab-Islamic Philosophy: A Contemporary Critique. Austin: Center for Middle Eastern Studies, University of Texas at Austin.

Jaiz, Hartono Ahmad. I99I. Di Bawah Bayang-bayang Soekarno Soeharto: Tragedi Politik Islam Indonesia dari Orde Lama hingga Orde Baru. Jakarta: Darul Falah.

Jamhari \& Fuad Jabali (eds). 2002. Islam in Indonesia: Islamic Studies and Social Transformation. Montreal \& Jakarta: Indonesia-Canada Islamic Higher Education Project.

Jamhari \& Jajang Jahroni (eds.). 2004 Gerakan Salafi Radikal di Indonesia. Jakarta: RajaGrafindo Persada.

Jay, Robert R. I963. Religion and Politics in Rural Central Java, Cultural Report Series, No. I2, New Haven: Yale University.

Jong, Kees de. 2009. 'Religious (Peace) Education as a means to avert threats to religious harmony in Indonesia'. In: Carl Sterkens, Muhammad Machasin \& Frans Wijsen (eds.), Religion, Civil Society and Conflict in Indonesia, pp. I53-I72. Berlin \& Zürich: LIT.

Josie M.F. \& Abdul Rahim Ibrahim (eds.). 2002. A Giving Society: The State of Philanthropy in Malaysia. Penang: University Sains Malaysia, 2002.

Jurriëns, Edwin. 2003. 'Radio Komunitas di Indonesia: "New Brechtian Theatre” di Era Reformasi?’, Antropologi Indonesia, 72, pp. II6-г30.

Jurriëns, Edwin. 2007. 'The Cosmopatriotism of Indonesia's Radio-Active Public Sphere'. In: Edwin Jurriëns \& Jeroen de Kloet (eds.), Cosmopatriots: On Distant Belongings and Close Encounters, pp. I05-I32. Amsterdam \& New York: Rodopi, B.V.

Kaptein, Nico J.G. 2004. 'The Voice of 'Ulamā': Fatwas and Religious Authority in Indonesia', Archives de Sciences Sociales des Religions, I25, pp. II5-I3O.

Karam, Azza M. I998. Women, Islamism and the State: Contemporary Feminisms in Egypt. New York: St Martin's Press.

Karim, M. Rusli. I999. Negara dan Peminggiran Politik Islam. Yogyakarta: Tiara Wacana.

Keane, John. I996. Reflections on Violence. London: Verso.

King, Dave. I993. The Transvestite and Transsexual. Public Categories and Private Identities. Avebury: Aldershot.

Klinken, Gerry van. 2007. Communal Violence and Democratization in Indonesia: Small Town Wars. Oxford \& New York: Routledge.

Koentjaraningrat. I985. Javanese Culture. Singapore: Oxford University Press.

Koeswinarno. I989. Waria dan problematika seksual. Yogyakarta: Pusat Penelitian dan Kependudukan Universitas Gadjah Mada.

Koeswinarno. I997. Hidup sebagai waria. Yogyakarta: LKiS.

Krafess, Jamal. 2005. 'The Influence of the Muslim Religion in Humanitarian Aid', International Review of the Red Cross, 87 (858), pp. 327-42. 
Kurnia, Eka. 2007. Poligami. Siapa Takut? Perdebatan Seputar Poligami. Jakarta: QultumMedia.

Kusmana \& Yudhi Munadi. 2002. Proses Perubahan IAIN Menjadi UIN Syarif Hidayatullah Jakarta: Rekaman Media Massa. Jakarta: UIN Jakarta Press.

Laderman, Carol. 1991. Taming the Wind of Desire: Psychology, Medicine, and Aesthetics in Malay Shamanistic Performance. Berkeley: University of California Press.

Laffan, Michael. 2003. Islamic Nationhood and Colonial Indonesia: The Umma Below the Winds. SOAS/RoutledgeCurzon studies on the Middle East. London: RoutledgeCurzon.

Laffan, Michael. 2004. 'An Indonesian Community in Cairo: Continuity and Change in a Cosmopolitan Islamic Milieu', Indonesia, 77, April, pp. I-26.

Laffan, Michael. 2006. What is Indonesian Islam? UC Los Angeles: UCLA Center for Southeast Asian Studies. Available at: www.escholarship.org/uc/item/5rz3p932 (Accessed I2/ 22/2010).

Latief, Hilman. 2010. 'Health Provision for the Poor: Islamic Aid and the Rise of Charitable Clinics in Indonesia', South East Asia Research, I8 (3), pp. 503-225.

Latief, Hilman. 20I0a. 'Youth, Mosque, and Islamic Activism: Islamic Sources Books in University-based Halaqah', Kultur, 5 (I), pp. 63-88.

Liddle, R. William. I996. 'The Islamic Turn in Indonesia: A Political Explanation', The Journal of Asian Studies, 55 (3), pp. 6r3-34.

Liddle, R. William I999. 'Skriptualisme Media Dakwah: Suatu Bentuk Pemikiran dan Aksi Politik Islam di Indonesia Masa Orde Baru'. In: Mark R. Woodward (ed.), Jalan Baru Islam, Memetakan Paradigma Mutakhir Islam Indonesia, pp. 283-3II. Bandung: Mizan.

Loebis, A.B. n.d. Pengadilan Negeri Jakarta in Action: Jurisprudensi Hukum Adat Warisan. Jakarta: n.p.

LSI. 2007. 'Trend Dukungan Nilai Islamis versus Nilai Sekular di Indonesia'. www.lsi.or.id/ riset/3IO/trend-dukungan-nilai-islamis-versus-nilai-sekular. Accessed 20 November 2007.

Lubis, Nur Ahmad Fadhilah. 2004. 'Financial Activism among Indonesian Muslims'. In: Virginia Hooker \& Amin Saikal, Islamic Perspective on the New Millennium, pp. 9I-II2. Singapore: ISEAS.

Lucas, Anton \& Robert Cribb. I997. 'Women's Roles in the Indonesian Revolution: Some Historical Reflections'. In: Taufik Abdullah (ed.), The Heartbeat of Indonesian Revolution, pp. 79-93. Jakarta: PT Gramedia.

Lukens-Bull, Ronald A. 200I. 'Two Sides of the Same Coin: Modernity and Tradition in Islamic Education in Indonesia', Anthropology \& Education Quarterly 32 (3), pp. 350-372.

Maarif, Ahmad Syafii. 2009. Islam dan Bingkai Keindonesiaan dan Kemanusiaan. Jakarta: Mizan.

Machasin, Aswab. I990. 'The Santri Middle Class: An Insider's View'. In: Richard Tanter \& Kenneth Young (eds.) The Politics of Middle Class, pp. 138-44. Clayton: Centre of Southeast Asian Studies, Monash University.

Machasin, Muhammad. 2009. 'The Islamic Fundamentalist Movement and its Impact on Pluralism in Indonesia'. In: Carl Sterkens, Muhammad Machasin \& Frans Wijsen (eds.), Religion, Civil Society and Conflict in Indonesia, pp. 27-40. Berlin \& Zürich: LIT.

Madjid, Nurcholish. I981. Integrasi Keislaman dalam keIndonesiaan untuk Menatap Masa Depan Bangsa. Jakarta: Yayasan Wakaf Paramadina.

Madjid, Nurcholish. I987. Islam, Kemodernan, dan Keindonesiaan. Bandung: Mizan.

Madjid, Nurcholish. I992. Islam, Doktrin dan Peradaban. Jakarta: Yayasan Wakaf Paramadina.

Madjid, Nurcholish. I994a. 'Islam di Indonesia dan Potensinya sebagai Sumber Substansiasi Ideologi dan Etos Nasional'. In: Budhy Munawar Rachman (ed.), Kontekstualisasi Doktrin Islam dalam Sejarah, pp. 568-58I. Jakarta: Yayasan Wakaf Paramadina. 
Madjid, Nurcholish. I994b. 'Taqlid dan Ijtihad: Masalah Kontinuitas dan Kreativitas dalam Memahami Pesan Agama'. In: Budhy Munawar Rachman (ed.), Kontekstualisasi doktrin Islam dalam sejarah, pp. 339-354. Jakarta: Yayasan Wakaf Paramadina.

Madjid, Nurcholish. I997. Tradisi Islam: Peran dan Ffungsinya dalam Pembangunan di Indonesia. Jakarta: Paramadina.

Madjid, Nurcholish. 2004. Indonesia Kita. Jakarta: Gramedia Pustaka Utama \& Universitas Paramadina.

Madjid, Nurcholish. 2005. Islam Doktrin dan Peradaban: Sebuah Telaan kritis tentang masalah Keimanan, Kemanusiaan dan Kemodernan. Fifth edition. Jakarta: Yayasan Wakaf Paramadina.

Mahmood, Saba. 2005. Politics of Piety. The Islamic Revival and the Feminist Subject. Princeton, NJ: Princeton University Press.

Mahmood, Saba. 2о0га. 'Feminist Theory, Embodiment, and the Docile Agent. Some Reflections on the Egyptian Islamic Revival', Cultural Anthropology I6 (2), pp. 202-236.

Mahmood, Saba. 200Ib. 'Rehearsed Spontaneity and the Conventionality of Ritual. Discipline of "Salat", American Ethnologist 28 (4), pp. 827-853.

Mahmood, Tahir. I972. Family Law Reforms in the Muslim World. New Delhi: The Indian Institute.

Mahmood, Tahir. 1987. Personal Law in Islamic Countries. New Delhi: Academy of Law and Religion.

Majlis Tafsir Al-Qur'an. n.d. Kumpulan Brosur Ahad Pagi Tahun 2006. Surakarta: Yayasan MTA.

Majlis Tafsir Al-Qur'an. n.d. Kumpulan Brosur Ahad Pagi Tahun 2007, Surakarta: Yayasan MTA.

Majlis Tafsir Al-Qur'an. n.d. Kumpulan Brosur Ahad Pagi Tahun 2008, Surakarta: Yayasan MTA.

Majlis Tafsir Al-Qur'an. n.d. Sunnah dan Bid'ah. Surakarta: MTA.

Majlis Tafsir Al-Qur'an. n.d. Surat Al-Baqarah Ayat 142-176. Surakarta: Yayasan MTA.

Majlis Tafsir Al-Qur'an. n.d. Surat Al-Baqarah Ayat 92-141. Surakarta: Yayasan MTA.

Majlis Tafsir Al-Qur'an. n.d. Surat Al-Fatihah dan Al-Baqarah Ayat 1-39. Surakarta: Yayasan MTA.

Majlis Tafsir Al-Qur'an. 2005. Tuntunan Ibadah Shalat Menurut Contoh Rosulullah SAW. Surakarta: MTA.

Majlis Tafsir Al-Qur'an. 2009. Brochure of Pengajian Ahad Pagi, 23 August 2009.

Majlis Tafsir Al-Qur'an. 20I0. Brochure of Pengajian Ahad Pagi, 31 October 2010.

Makdisi, George. I98I. The Rise of Colleges: Institutions of Learning in Islam and the West. Edinburgh: Edinburgh University Press.

Marcoes-Natsir, Lies \& John Hendrik Meuleman. I993. Wanita Islam Indonesia Dalam Kajian Tekstual dan Kontekstual. Jakarta: INIS.

Margoliouth, D. S. I997. 'Kadiriyya'. In: Encyclopaedia of Islam, 2nd ed., vol. 4, pp. 382-383. Leiden: E.J. Brill.

Marzuki, Rumadi Wahid. 2ooI. Figh Madzhab Negara: Kritik atas Politik Hukum Islam di Indonesia. Yogyakarta, LKIS.

Mas'oed, Mohtar. I989. Ekonomi dan Struktur Politik Orde Baru 1966-1971. Jakarta: LP3ES.

Mastuhu. I994. Dinamika Sistem Pendidikan Pesantren. Jakarta: INIS.

Mas'udi, Masdar F. I997. Islam dan Hak-hak Reproduksi Perempuan. Dialog Fiqih Pemberdayaan. Bandung: Mizan.

McCargo, Duncan. 2003. Media and Politics in Pacific Asia. London: RoutledgeCurzon.

Means, Gordon P. 2009. Political Islam in Southeast Asia, Petaling Jaya: Strategic Information and Research Development Centre.

Mehdi, Rubya. I989. Islamization of the Law in Pakistan. Richmond: Curzon Press. 
Messick, Brinkley. 1996. 'Media Muftis: Radio Fatwas in Yemen'. In: M.K. Masud, B. Messick \& D.S. Powers (eds.), Islamic Legal Interpretations: Muftis and Their Fatwas, pp. 3II-20. Cambridge: Harvard University Press.

Meuleman, Johan Hendrik \& Henri Chambert-Loir. I997. 'Les instituts Islamiques publics Indonésiens'. In Nicole Grandin and Marc Gaborieau (eds.), Madrasa: La Transmission du Savaoir dans le Monde Musulman, pp. I95-212. Paris: Éditions Arguments.

Mietzner, Marcus. 2008. 'Comparing Indonesia's Party Systems of the I950s and the PostSuharto Era: From Centrifugal to Centripetal Inter-Party Competition', Journal of Southeast Asian Studies, 39 (3), pp. 43I-53.

Milner, Anthony. I995. The Invention of Politics in Colonial Malaya: Contesting Nationalism and the Expansion of the Public Sphere. Cambridge: Cambridge University Press.

Misrawi, Zuhairi. 20II. 'Revitalisasi Islam 'Rahmatan lil 'Alamin”, Kompas daily newspaper, 3 January 20 II.

Mitchell, Richard P. I969. The Society of the Muslim Brothers. New York: Oxford University Press.

Mitsuo, Nakamura, Sharon Siddique \& Omar Farouk Bajunid. 20oI. Islam and Civil Society in Southeast Asia. Singapore: ISEAS.

Mols, Luitgard. 20I0. Passie voor Perfectie. Islamitische Kunst uit de Khalili Collecties. Amsterdam: Museumshop De Nieuwe Kerk.

Moosmüller, Alois. I989. The Pesantren auf Java: zur Geschichte der islamischen Zentren und ihrer gegenwärtigen gesellschaftlichen und kulturellen Bedeutung. Frankfurt: Lang.

Mrázek, Rudolf. I997. “Let Us Become Radio Mechanics”: Technology and National Identity in Late-Colonial Netherlands East Indies', Society for Comparative Study of Society and History, 39 (I), pp. 3-33.

Mudzhar, Mohamad Atho. I993. Fatwas of the Council of Indonesian Ulama: A Study of Islamic Legal Thought in Indonesia, 1975-1988. Jakarta: Indonesian-Netherlands Cooperation in Islamic Studies.

Muhamad, Hisyam et al. 2006. Budaya Kewargaan Komunitas Islam di Daerah Aman dan Rentan Konflik. Jakarta: LIPI Press.

Muhammad K. Husein. 200I. Fiqh Perempuan, Refleksi Kiai atas Wacana Islam Indonesia. Yogyakarta \& Jakarta: Rahima \& LKiS.

Muhammad K. Husein, Abdul Kodir Faqihuddin, Lies Marcoes Natsir \&Wahid Marzuki. 2006. Dawrah Fiqh Concerning Women: Manual for a Course on Islam and Gender. Cirebon: Fahmina Institute.

Mujani, Saiful \& R. William Liddle. 2007. 'Leadership, Party, and Religion: Explaining Voting Behavior in Indonesia', Comparative Political Studies 40 (7), pp. 832-57.

Mujiburrahman. I999. 'Islam and Politics in Indonesia: The Political Thought of Abdurrahman Wahid', Islam and Christian-Muslim Relations Io (3), pp. 339-352.

Mujiburrahman. 2009. 'Mengindonesiakan Islam'. Paper for the workshop on Islam dan Masa Depan Indonesia organised by PSIK-Indonesia and UIN Suska, Pekanbaru, 2I June 2009 .

Mulder, Niels. 2005. Mysticism in Java: Ideology in Indonesia. Yogyakarta: Kanisius.

Mulder, Niels. 1978. Mysticism and Contemporary Life in Everyday Java. Singapore: Singapore University Press.

Mulia, Musdah. I999. Pandangan Islam tentang Poligami. Jakarta: Lembaga Kajian Agama \& Gender.

Mulia, Siti Musdah. 2007. Islam Menggugat Poligami. Jakarta: Gramedia.

Mulyadi, Sukidi. 2003. 'Violence under the Banner of Religion: The Case of Laskar Jihad and Laskar Kristus', Studia Islamika, ıо (2), pp. 75-IIо.

Munawar-Rachman, Budhy. 2010a. Reorientasi Pembaruan Islam: Sekularisme, Liberalisme, dan Pluralisme Paradigma Baru Islam Indonesia. Jakarta: LSAF and Paramadina. 
Munawar-Rachman, Budhy. 2oIob. Sekularisme, Liberalisme and Pluralisme: Islam Progresif dan Perkembangan Diskursusnya. Jakarta: Grasindo.

Munhanif, Ali. 2000. 'Muhammad Natsir: Berdakwah di Dunia Politik Berpolitik Melalui Dakwah', Jurnal Komunikasi Dunia Perguruan Madrasah, 3 (3).

Munir, Lily. I999. Memposisikan Kodrat: Perempuan dan Perubahan dalam Perspektif Islam. Bandung: Mizan.

Murillo, Mario Alfonso. 2003. 'Community Radio in Colombia: Civil Conflict, Popular Media and the Construction of a Public Sphere', Journal of Radio a Audio Media, Io (I), pp. I2OI40.

Murtopo, Ali. I974. Strategi Politik Nasional. Jakarta: Yayasan Proklamasi dan CSIS.

Muzakki, Akh. 2007. 'Islam as a Symbolic Commodity: Transmitting and Consuming Islam through Public Sermons in Indonesia'. In: Pattana Kitiarsa (ed.), Religious Commodifications in Asia: Marketing Gods, pp. 205-I9. London: Routledge.

an-Na'im, Abdullahi Ahmed. 2008. Islam and the Secular State. Negotiating the Future of Shari'a. Cambridge: Harvard University Press.

Nadia, Zunly. 2005. Waria. Laknat atau kodrat? Yogyakarta: Galang Press.

Nadjib, Emha Ainun. I994.'Dialog antar Agama dan Batas-batasnya'. In: Th. Sumartana et al. (eds.), Dialog: Kritik dan Identitas Agama, pp. I42-5. Yogyakarta: Pustaka Pelajar.

Nadjib, Emha Ainun. 2007. Kiai Bejo, Kiai Untung, Kiai Hoki. Jakarta: Kompas.

Nakamura, Mitsuo. I983. The Crescent Arises over the Banyan Tree. Yogyakarta: Gadjah Mada University Press.

Nasir, Abdul Halim. I995. Seni Bina Masjid di Dunia Melayu-Nusantara. Bangi: Penerbit Universiti Kebangsaan Malaysia.

Natsir, Mohammad. I955. Capita Selecta. Bandung \& s'Gravenhage: W. van Hoeve.

Naufal bin Muhammad Al-Aidrus. 2007. Mana Dalilnya 2: Maulid Nabi, Sunah atau Bid'ah, 7 th ed. Surakarta: Taman Ilmu.

Naufal bin Muhammad Al-Aidrus. 2009. Anda Bertanya Salaf Menjawab I, 4th ed. Surakarta: Taman Ilmu.

Newsweek. 1996. 'Islam with a Smiling Face', 23 September.

Nieuwenhuijze, C.A.O. van. I985. Aspects of Islam in Post Colonial Indonesia. The Hague: W. Van Hoeve.

Nock, A.D. I933. Conversion: The Old and the New Religion from Alexander the Great to Augustine of Hippo. Oxford: Clarendon Press.

Noer, Deliar. I988. 'Contemporary Political Dimensions of Islam'. In: M.B. Hooker (ed.), Islam in South-East Asia, pp. I83-220. Leiden: Brill.

Noer, Deliar. I996. Gerakan Moderen Islam di Indonesia 1900-1942, 8th ed. Jakarta: LP3ES.

Noer, Deliar. I973. The Modernist Muslim Movement in Indonesia, 1900-1942. Oxford: Oxford University Press.

Noer, Deliar. I983. Islam, Pancasila dan Asas Tunggal. Jakarta: Yayasan Perkhidmatan.

Noor, Farish, A. 2007. 'Ngruki Revisited: Modernity and Its Discontents at the Pondok Pesantren al-Mukmin of Ngruki, Surakarta', Working Paper, S. Rajaratnam School of International Studies, Singapore.

Nurlaelawati, Euis. 20I0. Modernization, Tradition and Identity: The Kompilasi Hukum Islam and the Legal Practice of the Indonesian Religious Court. The Netherlands: Amsterdam University Press.

Nurmila, Nina 2009. Women, Islam and Everyday Life: Renegotiating Polygamy in Indonesia. New York \& London: Routledge.

Nurmila, Nina. 20II. 'The Influence of Global Muslim Feminism on Indonesian Muslim Feminist Discourse', Al-Jāmi ‘ah, 49 (I), pp. 33-64.

Nyman, Mikaela. 2006. Democratizing Indonesia: The Challenges of Civil Society in the Era of Reformasi. Denmark: NIAS Press. 
O' Flaherty, Michael \& John Fisher. 2008. 'Sexual Orientation, Gender, Identity, and International Human Rights Law. Contextualizing the Yogyakarta Principles', Human Rights Law Review, 8 (2), pp. 208-213.

O' Shaugnessy, Kate. 2009. Gender, State, and Social Power in Contemporary Indonesia. Divorce and Marriage Law. New York: Taylor and Francis Group.

Passion. 2010. Passion for Perfection [Catalogue of the exhibition Passion for Perfection: Islamic Art from the Khalili Collections]. Amsterdam: De Nieuwe Kerk.

PIRAC. 2002. Giving and Fundraising in Indonesia. Manila: Asian Development Bank.

Peletz, Michael G. 2006. 'Transgenderism and Gender Pluralism in Southeast Asia', Current Anthropology 47 (2), pp. 309-340.

Peletz, Michael G. 2009. Gender Pluralism: Southeast Asia since Early Modern Times. New York: Routledge.

Pellat, Ch. DATE 'Manakib'. In: Encyclopaedia of Islam, 2nd ed., vol. 6, pp. 349-357.

Pelras, Christian. 1996. The Bugis. Oxford: Blackwell.

Penders, C. L. M. 1977. Indonesia: Selected Documents on Colonialism and Nationalism, 18301942. St. Lucia: University of Queensland Press.

Pepinsky, Thomas B. 2009. Economic Crises and the Breakdown of Authoritarian Regimes Indonesia and Malaysia in Comparative Perspective. New York: Cambridge University Press.

Petrus Blumberger, J.Th. I93I. De Nationalistische Beweging in Nederlandsch-Indië. Haarlem: H.D. Tjeenk Willing \& Zoon.

Pigeaud, Th.G.Th. 1960-1963. Java in the $14^{\text {th }}$ Century. 5 Vols. The Hague: Martinus Nijhoff.

Platzdasch, Bernhard. 2009. Islamism in Indonesia: Politics in the Emerging Democracy. Singapore: ISEAS.

PPIM. 2007. 'Appendix: Indonesian Muslim Attitudes on Islamism and Democracy'. Unpublished Research Report, Project on Islam and Education in Southeast Asia. Boston: Institute on Culture, Religion, and World Affairs, Boston University.

Prawiranegara, Sjafruddin. I984. 'Pancasila as the Sole Foundation', Indonesia, 38, pp. 74-83.

Putnam, Robert. I994. Making Democracy Work: Civic Traditions in Modern Italy. Princeton: Princeton University Press.

Qureshi, Jawad Hussain. 2006. 'Earthquake Jihad: the Role of Jihadists and Islamist Groups after the October 2005 Earthquake', Humanitarian Exchange, 34 (June 2006), pp. 6-8.

Rabaza, Angels. 20Io. Deradicalizing Islamist Extremists. Arlington, VA: Rand National Security Research Division.

Rahman, Fazlur. I982. Islam a Modernity: Transformation of an Intellectual Tradition. Chicago: University of Chicago Press.

Rahman, Fazlur. 1984. Islam and Modernity: Transformation of an Intellectual Tradition. Chicago: Univ. of Chicago.

Rahmat, M. Imdadun. 2008. Ideologi Politik PKS: Dari Masjid Kampus ke Gedung Parlemen. Yogyakarta: LKiS.

Raillon, François. I993. 'The New Order and Islam, or the Imbroglio of Faith and Politics', Indonesia, 57, pp. I97-217.

Ramage, Douglas Edward. 1993. Ideological Discourse in the Indonesian New Order: State Ideology and the Beliefs of an Elite, 1985-1993. PhD dissertation, University of South Carolina.

Rasdi, Mohamad Tajuddin Mohamad. 2009. 'The Architecture of Putrajaya: Power, Democracy and Islamic Values', New Malaysian Essays Vol. 2, pp. 43-6r. Petaling Jaya: Matahari Books.

Rasmussen, Anne K. 20I0. Women, the Recited Qur'an, and Islamic Music in Indonesia. Berkeley \& Los Angeles, California: University of California Press. 
Al-Raysuni, Ahmad. 2005. Imam al-Shatibi's Theory of the Higher Objectives and Intents of Islamic Law. London and Washington: International Institute of Islamic Thought.

Reenen, Joke van. I996. Central Pillars of the House: Sisters, Wives, and Mothers in a Rural Community in Minangkabau, West Sumatra. Leiden, The Netherlands: Research School CNWS.

Reid, Anthony. 1990. Southeast Asia in the Age of Commerce, 1450-1680: Volume One, The Lands below the Winds. New Haven: Yale University Press.

Reid, Anthony. 1993. Southeast Asia in the Age of Commerce, 1450-1680. Volume Two: Expansion and Crisis. New Haven \& London: Yale University Press.

Ricklefs, Merle Calvin. 2006. Mystic Synthesis in Java: A History of Islamization from the Fourteenth to the Early Nineteenth Centuries. Norwalk, USA: EastBridge.

Ricklefs, Merle Calvin. 2007. Polarising Javanese Society, Islamic and other Visions (c. 18301930). Singapore: NUS Press.

Ricklefs, M.C. 2008. 'Dynamic in Java: Historical and Contemporary Rhymes'. In: Greg Fealy \& Sally White (eds.), Expressing Islam: Religious Life and Politics in Indonesia, pp. II536. Singapore: ISEAS Publishing.

Ridwan, Nur Khalik. 2007. 'Majelis Ulama Indonesia dan Ambivalensi Organisasi Ulama', Tashwirul Afkar, 2I, pp. 75-90.

Rinaldo, Rachel. 2008 'Muslim Women, Middle Class Habitus, and Modernity in Indonesia', Contemporary Islam, 2, pp. 23-39.

Robinson, Francis. I993. 'Technology and Religious Change: Islam and the Impact of Print', Modern Asian Studies, 27 (I), pp. 229-51.

Rofiq, Ahmad. I995. Fiqih Mawaris. Jakarta: RajaGrafindoPersada.

Sabra, A.I. I987. 'The Appropriation and Subsequent Naturalization of Greek Science in Medieval Islam', History of Science, 25, pp. 223-43.

Sabrie, Zufran et al., 200I. Laporan Hasil-Hasil Monitoring dan Evaluasi (Penelitian Pelaksanaan Undang-Undang Peradilan Agama dan Kompilasi Hukum Islam. Jakarta: Ditbinbapera Departemen Agama.

Saeed, Abdullah. 2006. Interpreting the Qur'an: Towards a Contemporary Approach. New York: Routledge.

Safi, Omid. 2003. 'Introduction'. In: Omid Safi (ed.), Progressive Muslims. On justice, gender, and pluralism. Oxford, UK: Oneworld Publications.

Saifullah Ma'shum \& Ali Zawawi (eds.). 1996. 50 Tahun Muslimat NU, Berkhidmat untuk Agama, Negara \& Bangsa. Jakarta: Pucuk Pimpinan Muslimat Nahdlatul Ulama

Saimina, Iqbal Abdurrauf. I988. Polemik Reaktualisasi Ajaran Islam. Jakarta: Pustaka Panjimas.

Saleh, Fauzan. 200I. Modern Trends in Islamic Discourse in the $20^{\text {th }}$ Century Indonesia. Leiden: Brill.

Salim, Arskal. 2008. Challenging the Secular State: The Islamization of Law in Modern Indonesia. Honolulu: University of Hawai'i Press.

Salim, Arskal \& Azyumardi Azra. 2003. Shari'a and Politics in Modern Indonesia. Singapore, ISEAS.

Salim, Hairus. 20ıо. 'Pentingnya 'Politik Pengakuan' dalam Pengelolaan Masyarakat Multikultural', Kentongan, pp. 2-4. Salatiga: Percik.

Salim, et al. 2009. Demi Keadilan dan Kesetaraan: Dokumentasi Program Sensitivitas Jender Hakim Agama. Jakarta: PUSKUMHAM.

Samson, Allan A. I972. 'Army and Islam in Indonesia', Pacific Affairs, 44 (4), pp. 545-565.

Schulze, Fritz. 2008. 'Die Konzeption von Pluralismus in neo-modernistischen Islam Indonesien'. In: Fritz Schulze \& Holger Warnk (eds.), Religion und Identität: Muslime und Nicht-Muslime in Südostasien, pp. 65-76. Wiesbaden: Harrassowitz. 
Sciortino, Rosalia et al. .2010. 'Caught between Social and Market Considerations: A Case Study of Muhammadiyah Charitable Health Services', Reproductive Health Matters, I8 (36), pp. 25-34.

Scott, James. I990. Domination and the Art of Resistance. Hidden Transcript. New Haven: Yale University Press.

Sedgewick, 2009. Muhammad Abduh. Oxford: One World.

Sen, Krishna \& David T. Hill. 2000. Media, Culture and Politics in Indonesia. Oxford: Oxford University Press.

Shaltut, Mahmud. 2002. Al-Fatawa: Dirasat li Mushkilat al-Muslim al-Ma'asir fi Hayatihi alYawmiyah al-'Ammah. 8th edition. Cairo: Dar al-Shuruq.

Shaw-Hamilton, James. 2007. 'Recognizing the Umma in Humanitarianism: International Regulation of Islamic Charities'. In: Jon B. Alterman \& Karin von Hippel, Understanding Islamic Charities, pp. I5-3I. Georgetown: Center for Strategic and International Studies.

Shihab, Alwi. I991. Islam Sufistik: 'Islam Pertama' dan Pengaruhnya hingga Kini di Indonesia. Bandung: Mizan.

Shiraishi, Takashi. I990. An Age in Motion: Popular Radicalism in Java, 1912-1926. Ithaca \& London: Cornell University Press.

Sila, M. Adlin. 2009. 'Pemetaan Varian Kesamamaan Islam Kontemporer: Kasus Gerakan Salafi di Indonesia'. In: Prosiding Muncul dan Berkembangnya Varian Keagamaan Islam Kontemporer di Indonesia: Islam, Negara-Bangsa, dan Globalisasi. Jakarta: PMB-LIPI bekerjasama dengan Institute for Languages and Cultures of Asia and Africa, Tokyo University of Foreign Studies.

Slamet, Mhd. I990. 'Comment on Aswab Mahasin's “The Santri Middle Class: An Insider's View”'. In: Richard Tanter \& Kenneth Young (eds.), The Politics of Middle Class, pp. I45-6. Clayton: Centre of Southeast Asian Studies, Monash University.

Smith-Hefner, Nancy J. 2006. 'Reproducing Respectability: Sex and Sexuality among Muslim Javanese Youth', Review of Indonesian and Malaysian Affairs 40 (I), pp. I43-I72.

Smith-Hefner, Nancy J. 2007. 'Javanese Women and the Veil in Post-Soeharto Indonesia', The Journal of Asian Studies, 66 (2), pp. 389-420.

Snouck Hurgronje, C. I9I5. Nederland en de Islam. Leiden: Brill. (2nd enlarged edition).

Soekarno. I970. Nationalism, Islam and Marxism. Translated by Karel H. Warouw and Peter D. Weldon. Ithaca, New York: Modern Indonesian Project, Southeast Asia Program, Department of Asian Studies, Cornell University.

Stange, Paul. I986. “ ' Legitimate” Mysticism in Indonesia', Review of Indonesian and Malaysian Affairs, 20 (2), pp. 76-II7

Strathern, Andrew J. I996. Body Thoughts. Ann Arbor: University of Michigan Press.

Suaedy, Ahmad. 2007. 'Pluralisme sebagai Kerangka Kerja'. In: Imam Subkhan (ed.), Hiruk Pikuk Wacana Pluralisme di Yogya, pp. 7-II. Yogyakarta: Kanisius.

Subakir, Ahmad, Ilham Masyhuri \& M. Asror Yusuf. 2007. 'Respons Tokoh Islam atas fatwa MUI tentang Gerakan Ahmadiyah Indonesia', ERN, 3 (6), pp. I-36, http://ern.pendis. kemenag.go.id/DokPdf/ern-III-o6.pdf, accessed on 7 December 2010.

Subhan, Zaitunah. I999. Tafsir Kebencian: Studi Bias Jender dalam Tafsir al-Qur'an. Yogyakarta: LKiS.

Subkhan, Imam (ed.). 2007. Hiruk Pikuk Wacana Pluralisme di Yogya. Yogyakarta: Kanisius.

Sukma, Rizal. 20I0. 'Indonesia's 2009 Elections: Defective System, Resilient Democracy'. In: Edward Aspinall and Marcus Mietzner (eds.), Problems of Democratisation in Indonesia: Elections, Institutions, and Society, pp. 53-74. Singapore: Indonesia Update Series, Institute of Southeast Asian Studies.

Sumner, Cute \& Tim Lindsey, 20Iо. Courting Reform: Indonesia's Islamic Courts and Justice for the Poor, Lowy Institute for International Policy, Australia.

Suratman. 2008. Tuntunan Ngibadah Sholat Miturut Tuladhane Rosulullah SAW. Surakarta: MTA. 
Syamsuddin, M. Din. 2000. Islam dan Politik Era Orde Baru. Jakarta: Logos.

Syamsuri, Baidlowi. I995. Kisah Walisongo. Penyebar Agama Islam di Tanah Jawa. Surabaya: Apollo.

Tabari, Abu Ja‘far Muhammad b. Jarir al. 200I. Tafsir al-Tabari Jami’ al-Bayan 'An Ta’wil Ay al-Qur'an, vol. I8. Cairo: Hajr li al-Tiba'ah wa al-Nashr wa al-Tauzi‘ wa al-I'lan.

Tarling, Nicholas. I994. The Cambridge History of Southeast Asia. Volume Two: The Nineteenth and Twentieth Centuries. Cambridge: Cambridge University Press.

Taylor, Charles. 2004. Modern Social Imaginaries. Durham: Duke University Press.

Tim Pimpinan Pusat Muhammadiyah Majlis Tarjih (Team of Majlis Tarjih of Muhammadiyah). 2003. Tanya-jawab Agama I. Jakarta: Yayasan Penerbit Press 'Suara Muhammadiyah'.

Turner, Bryan. 2008a. The Body and Society. 3rd edition. London: SAGE Publications Ltd.

Turner, Bryan \& Joy Kooi-Chin Tong. 2008b. 'Women, Piety, and Practice. A Study of Women and Religious Practice in Malaysia', Contemporary Islam, 2, pp. 4I-59.

Ufen, Andreas. 2008. 'From Aliran to Dealignment: Political Parties in Post-Suharto Indonesia', South East Asia Research, I6 (I), pp. 5-4I.

UIN Jakarta. 2005. Prospectus: Fifth Edition, Syarif Hidayatullah State Islamic University, Jakarta, Indonesia. Jakarta: UNI Syarif Hidayatullah.

Umar, Nasaruddin. I999. Argumen Kesetaraan Jender. Perspektif Al-Qur'an. Jakarta: Paramadina.

Verslag. 1878/1879. Verslag der Handelingen van de Staten-Generaal. 's-Gravenhage: Algemeene Landsdrukkerij.

Vreede de Stuers, Cora. I959. L'émancipation de la femme indonésienne. Paris \& La Haye: Mouton \& Co.

Wahib, Ahmad Bunyani. n.d. Gerakan Dakwah Salafi Pasca Laskar Jihad. n.p.

Wahid, Abdurrahman. I983. 'Salahkah Jika Dipribumikan?' Tempo Magazine, I6 July I983.

Wahid, Abdurrahman. I986. 'The Nahdlatul Ulama and Islam in Present Day Indonesia'. In: Taufik Abdullah \& Sharon Siddique (eds.), Islam and society in Southeast Asia, pp. I75I85. Singapore: Institute of Southeast Asian Studies.

Wahid, Abdurrahman. I989. 'Pribumisasi Islam'. In: Muntaha Azhari \& Abdul Mun'im Saleh (eds.), Islam Indonesia menatap masa depan, pp. 8I-96. Jakarta: Perhimpunan Pengembangan Pesantren dan Masyarakat.

Wahid, Abdurrahman. I990. 'Indonesia's Muslim Middle Class: An Imperative or Choice?' In: Richard Tanter \& Kenneth Young (eds.), The Politics of Middle Class, pp. II-I4. Clayton: Centre of Southeast Asian Studies, Monash University.

Wahid, Abdurrahman. I994a. 'Universalisme Islam dan Kosmopolitanisme Peradaban Islam'. In: Budhy Munawar Rachman (ed.), Kontekstualisasi Doktrin Islam dalam Sejarah, pp. 545-552. Jakarta: Yayasan Wakaf Paramadina.

Wahid, Abdurrahman. I994b. 'Islam, Ideologi dan Etos Kerja di Indonesia'. In: Budhy Munawar Rachman (ed.), Kontekstualisasi Doktrin Islam dalam Sejarah, pp. 582-587. Jakarta: Yayasan Wakaf Paramadina.

Wahid, Abdurrahman. 2oo6. Islamku, Islam Anda, Islam Kita: Agama Masyarakat Negara Demokrasi. Jakarta: Wahid Institute.

Wahid, Abdurrahman. 2007. Islam Kosmopolitan: Nilai-nilai Indonesia \& Transformasi Kkebudayaan. Jakarta: Wahid Institute.

Wahid, Abdurrahman. 2008. 'Lagi-lagi Pribumisasi Islam'. Makalah Seminar \& Bedah Buku Satu Abad Kebangkitan Nasional, 27-29 May 2008. 
Wahid, Din. 2007. 'Islamic State or Islamic Society?'. In: Rizal Sukma \& Clara Juwono (eds.), Islamic Thought and Movements in Contemporary Indonesia, pp. 79-04. Jakarta: Centre for Strategic and International Studies (CSIS).

Wahyudi, Yudian. I993. Hasbi's Theory of Ijtihad in the Context of Indonesian Fiqh. MA thesis, Montreal: McGill University.

Ward, K.E. I970. The Foundation of The Partai Muslimin Indonesia. Ithaca (NY): Modern Indonesian Project, Southeast Asia Program, Cornell University.

Weber, Max. I968. 'Charisma and Institutionalization in the Legal System'. In: Eisenstads S.N. (ed.), Max Weber: On Charisma and Institution Building. Chicago: The University of Chicago Press.

Weber, Max. 2002. The Protestant Ethic and the Spirit of Capitalism and Other Writings. New York: Penguin.

Wehr, Hans. I976. A Dictionary of Modern Written Arabic, ed. J. Milton Cowan, 3rd ed. Wiesbaden: Otto Harrassowitz, Spoken Language Services, Inc.

Weis, Holger. 2002.'Reorganizing Social Welfare among Muslims: Islamic Voluntarism and other forms of Communal Support in Northern Ghana', Journal of Religion in Africa, 32 (I), pp. 83-Io9.

Weiss, Bernard G. I998. The Spirit of Islamic Law. Athens, GA: University of Georgia Press.

White, Sally \& Maria Ulfah Anshor. 2008. 'Islam and Gender in Contemporary Indonesia: Public Discourses on Duties, Rights and Morality'. In: Greg Fealy \& Sally White (eds.), Expressing Islam: Religious Life and Politics in Indonesia, pp. I37-I58. Singapore: ISEAS.

Wickham, Carrie Rosefsky. 2002. Mobilizing Islam: Religion, Activism, and Political Change in Egypt. New York: Columbia University Press.

Wiktorowicz, Quintan 200I. The Management of Islamic Activism: Salafis, the Muslim Brotherhood, and State Power in Jordan. Albany: State University of New York Press.

Widiyanto, Asfa. 2012. Ritual and Leadership in the Subud Brotherhood and the Tariqa Qadiriyya wa Naqshbandiyya. Berlin \& Hamburg: EB-Verlag.

Wieringa, Edwin. 2006. 'Moral Education through Islamic Songs in Twentieth Century Java'. In: Glenda Abramson \& Hilary Kilpatrick (eds.), Religious Perspectives in Modern Muslim and Jewish Literatures, pp. 90-III. New York: Routledge.

Wieringa, Saskia. 2002. Sexual Politics in Indonesia. The Hague: ISS, Palgrave.

Wieringa, Saskia. 2003. 'The Birth of New Order State in Indonesia. Sexual Politics and Nationalism', Journal of Women's History I5 (I), pp. 70-9I.

Wiktorowicz, Quintan. 2004. Islamic Activism: A Social Movement Theory Approach. Bloomington and Indianapolis: Indiana University Press.

Wiktorowicz, Quintant \& Suha Taji Farouki. 2000. 'Islamic NGOs and Muslim Politics: A Case from Jordan', Third World Quarterly, 2 (4), pp. 685-699.

Wildan, Muhammad. 2008. 'Mapping Radical Islamism in Solo: A Study of the Proliferation of Radical Islamism in Central Java, Indonesia', Al-Jami ‘ah, 46 (I), pp. 35-69.

Wildan, Muhammad. 2009. 'Radical Islamism in Solo: A Quest of Muslims' Identity in a Town of Central Java Indonesia.' PhD dissertation submitted to Institute of Malay World and Civilization, Universiti Kebangsaan Malaysia.

Winchester, Daniel. 2008. 'Embodying the Faith. Religious Practice and the Making of Muslim Moral Habitus', Social Forces 86 (4), pp. I753-I780.

Woodward, Mark. I988. 'The "Slametan": Textual Knowledge and Ritual Performance in Central Javanese Islam', History of Religions, 28 (I), pp. 54-89.

Woodward, Mark R. I989. Islam in Java. Normative Piety and Mysticism in the Sultanate of Yogyakarta. Tucson: The University of Arizona Press.

Woodward, Mark R. I996. 'Conversations with Abdurrahman Wahid'. In: Mark R. Woodward (ed.), Toward a New paradigm: Recent developments in Indonesian Islamic thought, pp. I33-I53. Tempe, Ariz: Arizona State University, Program for Southeast Asian Studies.

Woodward, Mark. 20Io. Java, Indonesia and Islam. London, New York: Springer. 
Wuthnow, Robert. I988. The Restructuring of American Religion: Society and Faith Since the Second World War. Princeton: Princeton University Press.

Wuthnow, Robert. 2003. Zaman, Muhammad Qasim. 2007. 'Tradition and Authority in Deobandi Madrasas of South Asia'. In: Robert W. Hefner and Muhammad Qasim Zaman (eds.), Schooling Islam: The Culture and Politics of Modern Muslim Education, pp. 6I-86.

Wuthnow, Robert. 20II. 'Pakistan: Shari'a and the State'. In: Robert W. Hefner (ed.), Sharia Politics: Islamic Law and Society in the Modern World, pp. 207-43. Bloomington: Indiana University Press. Princeton \& Oxford: Princeton University Press.

Yavuz, M. Hakan. 2004. 'Opportunity Spaces, Identity and Islamic Meaning in Turkey'. In: Quintan Wiktorowicz (ed.), Islamic Activism: A Social Movement Theory Approach, pp 270288. Bloomington \& Indianapolis: Indiana University Press.

Young, Kenneth. I990. 'Middle Bureaucrats, Middle Peasants, and Middle Class? The Extraurban Dimension'. In: Richard Tanter \& Kenneth Young (eds.), The Politics of Middle Class, pp. I47-I66. Clayton: Centre of Southeast Asian Studies, Monash University.

Young, M.J.L. I990. 'Arabic Biographical Writing'. In: M.J.L. Young, J.D. Latham \& R.B. Serjeant (eds.), Religion, Learning and Science in the 'Abbasid Period, p. I77. Cambridge: Cambridge University Press.

Yusuf Ali, Abdullah. 200I. The Meaning of the Holy Qur'an, New Edition with Qur'anic Text (Arabic), Revised Translation, Commentary and Newly Compiled Comprehensive Index. Beltsville, Maryland: Amana Publications.

Zaman, Muhammad Qasim. 2002. The Ulama in Contemporary Islam: Custodians of Change. Princeton \& Oxford: Princeton University Press.

Zeghal, Malka. 2007 'The 'Recentering' of Religious Knowledge and Discourse: The Case of Al-Azhar in Twentieth-Century Egypt'. In: Robert W. Hefner and Muhammad Qasim Zaman (eds.), Schooling Islam: The Politics and Culture of Islamic Education, pp. I07-I30. Princeton: Princeton University Press.

Zoelva, Hamdan. 2005. Impeachment Presiden: Alasan Tindak Pidana Pemberhentian Presiden Menurut UUD 1945. Jakarta: Konstitusi Press.

Zuhdi, Masjfuk. I993. Masail fighiyah. Kapita Selekta Hukum Islam. Jakarta: CV Haji Masagung.

Zuhri, Syaifudin. 2009. 'Gerakan Purifikasi di Jantung Peradaban Jawa'. In: Yudian Wahyudi (ed.), Gerakan Wahabi di Indonesia (Dialog dan Kritik), pp. 208-310. Yogyakarta: Pesantren Nawesea Press.

Zuhri, Syaifudin. 2010. 'Transnationalising Jamaah Islamiyyah', Al-Jami'ah, 48 (I), pp. 4580 .

Zulkifi, Zul Harmi. 2003. Sufi Jawa: Relasi Tasawuf-Pesantren. Yogyakarta: Pustaka Sufi. 


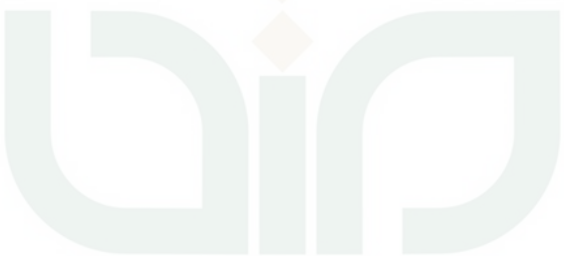

STATE ISLAMIC UNIVERSITY

$S U N A N \mid M A L \| / N G A$

YOG Y A K R T A 


\section{Index}

Aa Gym see Abdullah Gymnastiar Abangan 7, II, 25-26, 49-50, 57, I42, 223, 227-230, 239

Abduh, Muhammad 56 Abshar-Abdalla, Ulil 85-86 Abu Zayd, Nasr Hamid I2O-I2I Aceh I84-I85, I89-I90 Ahmadiyah 9, 76, I67-I70 Airlangga University I79 Aisyiyah I43-I44, I54, I86 ALARM I89, I93

Aliran 50, 56-57, 228-229

Alms giving 34, I80-I83

Amidhan, M. 168

AMP (Yayasan Amal Bakti Muslim Pancasila) 22

Anti-pornography law I4I, I50-I56 Arabic

- culture 28-30, 40, II8-II9, I24I26, I55

- language 28-30, I48, 218

Arabs 72, 197, 200, 230

Arkoun, Mohammad I45

Art, Islamic 20-2I

Asas tunggal 9, 3I-33, 80, I26, 22I223,229

Assalam pesantren I96

Assegaf, Ciciek Farha I46, I48

Assyaukanie, Luthfi 89, I70

Baasyir, Abu Bakar 72, I7I, I97, I99, 2I2-2I3, 230

Baasyir, Iim 2I3

Bali I55-I56

Banser Io
Barzanji 210, 230

Bedug 22-23

Bellah, Robert $37,4 \mathrm{I}$

Bisri, A Mustofa I62, I67-I72

Boas, Franz 29

Borobudur 40

BRR (Badan Rekonstruksi dan Rehabilitasi) I90

BSI (Bina Siswa Islami) 22I, 224225

BSMI (Red Crescent) I85, I87

Buddhism I7, 26, 40, I66, 239

By-laws 9, 77, I47-I48, I50, I55, I67

Caliphate 72

Charity I73-I93

Child marriage I47, I57

Christians 9, I6, I55-156, I66, I83, I88-I9O, 2I5, 239

Circumcision, female I47, I57, I59

Cirebon 215-225

Clinton, Hillary 70

Colonialism 32, 36-38, 4I

Customs, local 33-34, 43, 65-67, I23I3 6, I55, 228, 232-235, 238

Dakwah 76, 80-8I, 95-96, гоo, I42, I53, I69, I79-180, I83, I95-239

Darul Islam 8, 35, 229-230

Dauroh 200, 2I3

DDII I83, 215-2I6, 223-225

Democracy 39, 44-45, 57-59, 68-7I, 237

Dhikr 2II-2I2

Dompet Dhuafa I8I, I85-I87 
Dompet Peduli Umat Daarut Tauhid I80

Dress 7, 20, 3I, IOI-IO3, I47, I5O, I54-I56, 2I8-2I9, 224-225, 232233

Dwikarna, Agus 193

Egypt 54-58, I27, I75, I77, I79, 206

Fatayat NU I44-I47, I50, I56-I57

Fathullah, Lutfi I47

Fatwa 7, 98-99, 107, I53, I68-I70, 203-204

Feminists

- Muslim II3-II5, I39-I50, I55

- secular II3, I42-I43, I49-I5I

Forum Kajian Kitab Kuning I46

Forum Kajian Kitab Taqrib I47

Forum Pengkajian Islam I54

FPI 7, I0, 72-73, I63, I68, I85, I89

Gadjah Mada University I79, 2I6, 223

Geertz, Clifford I7-20, 28-29, 52, 64,240

Al-Ghazali 43-44

Golkar I56, 229

Great Britain 70

Gymnastiar, Abdullah I4I, I52-I53, 200

Habibie, B.J. $\quad 82-84$, I78-I79

Al-Habsy, Alwi 200

Hadikusumo, Ki Bagus 39

Hadith interpretation I47, 206-2IO

Haji 52, 80

Halaqah I79, I96, 213, 216

Hasbullah, Wahab I40

Hatta, Muhammad 38,79

Haz, Hamzah 70

Hazairin 33-34, I24-I26

Higher education, secular 179

Hinduism I7, 26, I55-156, 226, 239
Hizb al-Tahrir 43, 72-73, 85, III, II3, I65-I66, I7I, I85, I89, 222

HMI 84, I83-I84

Hodgson, Marshall S.S. I8

Homosexuals 92-I03

Husein, Muhammad III, II3, I47

ICMI 82-83, I78, I8I

Ikhwan al-Muslimin 56, 58, 72, I54, I65, I75, I79-I80

India 40, 43-44

Intellectuals, Muslim 77, 86-88, I25

Internet I99-20I, 2I3-2I4, 234-239

IPB 179

Iran 49, 68, I28, I77-I79, 2 I5

IRM (Ikatan Remaja Mesjid) 2I7225

Al-Irsyad 75, I97, 223, 228

Islam (in Indonesia)

- history 30, 4I-43, 5I-52, 58, 6367, Іо9-IIо, I6I, 226-227

- inferiority complex 28-29, 40, 67

- modernism 8, 27, 35-47, 52-53, 87, I28, I39-I40, I45, I77, 226 230

- radicalism 7I-73, 76, 85, I39, I52-I55, I63, I68, I89, I95-2I2, 215-239

- traditionalist 8, 27-34, 4I-47, 53, 87, I28, I44-I45, I5I, I57, 200, 204, 210, 226-230, 237

Islamic culture 40,43 Islamic education $34,49-54,67$, I44, 225, 23I, 238

- higher education 50, 54, 67, 86, I39-I40, I45, I49, I54, I56, I79

- madrasah 53-54

- pesantren 52-54, 94-98, I46I48, I6I, I96-202

- women 53, I44

Islamic high school associations II5225 
Islamic law

- compilation of Islamic law I23I38, I43, I49, I57

- courts I24, I33-I37

- family planning I45

- implementation 8, 35, 39, 59$62,85, \mathrm{I} 43,20 \mathrm{I}-202,222,232$

- inheritance 34, II5-I22, I24-I37, I49

- jihad I99, 222, 226

- jurisprudence 3I-34, 5I, I23-I36, I45-I47

- marriage 34, I23, I27-I36, I57

- music 202, 205-2I2

- polygamy I27, I33-I38, I4I-I54

Islamic state $33,39,72$

Islamic welfare associations 54-57, 67

ITB I79, 2I6, 223-224

Jakarta Charter 35, 39, 85

Jamaah Islamiyah 73, III, 2I2, 226

JAMI (Jamaah al-Ikhwan al-Muslimin Indonesia) 72-73

Jayabaya 43-44

JIL (Jaringan Islam Liberal) 89, I68-I7I

Journal of Indonesian Islam 43

Jurnal Perempuan 150

KAMMI 222

Kartini I42, I52

Khalili, Nasser D. 20

Khuntsa 98-100, I07

Komnas Perempuan I46

KOMPAK I83-I84, I93

Lady Gaga Io

Laskar Hizbullah 197

Laskar Jihad 7, 72-73, I63, I83-184, 225

LDK (Lembaga Dakwah Kampus) 223

Lesbians 92-IO3
Limrung, Tamsil I83, I93

Madina 37-38

Madjid, Nurcholish 27, 34-4I, 65, 8I, III, I45

Ma'had Darussalaf pesantren I98

Ma'had al-Ukhuwwah pesantren I98

Majapahit 43, I64

Majelis Tafsir Al-Qu'ran I96-I97, 227-239

Majelis taklim 76, I53, I80

Malay language 37

Malaysia I6, 22-23, I28-I33, I47, I57

Manji, Irshad IO-II

Marcoes-Natsir, Lies I46

Mariani 95-103, Io6

Marriage Law I23, I4I, I45, I5I

Marzuki, Abdullah I96

Masdar, F. Mas'udi III-II2, II6, II9, I46, I5O-I52

Masjumi 8-9, 77, 80, 89, 229

Mataram 30

Medan Moeslimin I7

Mer-C I84, I93

Middle class, Islamic 62, 67-68, I74-I80, I86, I9I-I92

Minangkabau 65, II8-II9

Ministry of Religious Affairs Io, 6769

Misrawi, Zuhairi 43

MMI $7,72,85,153,163,185,189$,

$$
222
$$

Moluccas I83-184, I88-189

Morocco I8-I9, I27

Mosques 2I-22, 30, I79, 216-2I7, $223,226,236$

Mosques, campus I79, 223

Muhammadiyah 8, I0, 55-57, 70-75, $80,89,94,99$, IIo, I40, I43I44, I53, I85-I86, I89-I9I, 228$229,233-236$

MUI 7, 10, 77, 88, 94, 98, I49, I63, I67-I70, I93 
Mujiburrahman 45

Al-Mukmin pesantren I96-I97, 2 I2

Mulia, Siti Musdah III, II3, I46, I5O, I54

Muslimat NU I44, I55-I56

Nadjib, Emha Ainun I62, I67-I72

Nahdlatul Ulama 8, I0, 3I-33, 42-43, 55-57, 70-75, 80-81, 94, 99, ІІо, I39-I40, I43-I49, I5I, I53, I57, I63, I70, I85, I89-I90, 204, 2102II, 228-229, 233-236

Nasyid 202-203, 208-209

Nationalism 36-40

Natsir, Mohammad 58,89

Natural disaster relief 95, I84-I92

Nawawi I46-I47

New Order 78-83

Nias I84-I85, I89-I9०

Nuriyah, Shinta I46, I52, I55

Osama bin Laden 73

OSIS 216,220

Pakistan 54, 58, I27-I33

Pancasila 8, 27, 3I-39, 60, 68-69, 84, I66-I67, I70, 223-224, 230

Papua I55

Parmusi 80

Partai Demokrat ${ }_{156} 6$

PBB 197

PDI-P I4I, I56

Penders, C.L.M. 25

Pengajian 95-96, I69, I80, 202, $230-236$

Penghulu 66-67

Perda syariah see by-laws

Persis 75, I85, 223, 228

Petrus Blumberger I7

PII 223

PKB ${ }_{156} 6$

PKO (People Kampong Organised) I90
PKPU (Pos Keadilan Peduli Umat)

I80-I82, I85, I87, I93

PKS 9, IIO, II3, I40, I47, I52-I53, I56, I8I-I82, 22I

Polygamy Award I52

Poso I83-I84, I88

PPP 85, I40

$\mathrm{P}_{3} \mathrm{M}$ I45-I46

Prambanan 40

Pribumisasi Islam 27-34, 45

Puan Amal Hayati I48

Puspita 148

Putrajaya 22

Qu'ran interpretation III-I22, I4I, I45, 23I-232

Qu'ran recite 80, 202

Radio stations, Christian 199

Radio stations, Islamic I95-2I2, 237

- Darussalaf FM I98-205

- Al-Madinah 202, 205

- Mentari FM 20I

- MTA FM I97-2I2, 233-237

- Radio ABC 197

- Radio Hizbullah 197

- RADIS I97, 230

- RDS FM I98-205

- Suara Al-Hidayah FM I99-205

- Suara Quran FM I98-2I2

- As-Sunnah 226

Rahardjo, Dawam I68

Rahima I46, I48

Rahman, Fazlur 46, III, I45

Reformasi era 9, 83-85, I43, I63, I80

Republika I8I

Ridho, Rasyid 199

Rifa'i, Ahmad 66-67

Rifka an-Nisa I5O

Rohana, Aan 153

Rohani Islam 216-225

Rumah Zakat Indonesia I80

Rusmanto, Yanni 197 
Santri 7, 49-50, I42, I77, 227-229

Saputra, Abdullah Thufail 196

Saudi Arabia 223, 226

Shalawat 206-2II, 230

Al-Shiddieqy, Hasbi 33-34, I24-126

Shihab, Habib Rizq 72

Shihab, Quraish I54

Sjadzali, Munawir 33-34, 65, II9-I2I, I24-I25, I43, I45, I49

Snouck Hurgronje, C I7-20, 36

Sufism Io9-iıo, I6I-I62, 204, 239

Suharto 8-9, 78, 223

Sukarno 8, 35, 78, 82, I5I

Sukarnoputri, Megawati 69-70, 84, ${ }_{15} 6$

Sukina, Ahmad 203, 230-239

Sulawesi Utara I55-I56

Sunan Kalijaga 30-3I

Sunan Kudus 30-3I

Sungkar, Abdullah I96, 212, 230

As-Sunnah 219-226

Surakarta I95-212, 226-239

Syamsudin, Din $\mathrm{I} 68$

Tablighi Jama'at $\mathrm{I}_{5}$

Tantri I48

Tarbiyah I54, I79, I8I-I82

Tashwirul Afkar 42

Terrorism 73, 76

Thalib, Ja'far Umar 72, 223, 225

Transgenders 92-IO3
Tufail, Abdullah 229-230, 236

TV stations 237

Al-Ukhuwah pesantren 200

Ulfa, Maria I46

Umar, Nasaruddin II3

Umma 38-39

Universitas Indonesia 179

Universitas Padjadjaran 224

Usroh 154

Wahid, Abdurrahman 27-34, 43-47, 65-66, 84, III, I43, I45, I49, I56I57, I68, I76-I77

Wali Songo 2I, 30-3I, IIO

Wardoyo, Puspo I52

Waria 93-I05

Women 69-70, 9I-I39, 204, 237

Woodward, M. I7-I8

World Vision I85, I90-I9I

Yayasan Dana Sosial Al-Falah I80

Yemen I95, I98

Yogyakarta I7, 9I-I07, I85

Youth Of The Streets I90

Yudhoyono, Susilo Bambang 234

Yusroh, Yoyoh I52-I53

Zainuddin MZ 200

Zakat see alms giving 


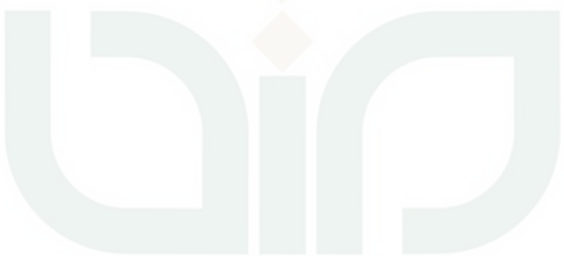

STATE ISLAMIC UNIVERSITY

$S U N A N \mid M A L \| / N G A$

YOG Y A K R T A 


\section{Publications Series}

\section{Monographs}

Hu Ping: The Thought Remolding Campaign of the Chinese Communist Party-state

Monographs 7, 2012 (ISBN 978908964 4IO 7)

Deborah E. Tooker: Space and the Production of Cultural Difference Among the Akha Prior to Globalization. Channeling the Flow of Life Monographs 6, 2012 (ISBN 9789089643254 )

Khun Eng Kuah-Pearce: Rebuilding the Ancestral Village. Singaporeans in China

Monographs 5, 20II (ISBN 978908964332 2)

Euis Nurlaelawati: Modernization, Tradition and Identity. The Kompilasi Hukum Islam and Legal Practice in the Indonesian Religious Courts Monographs 4, 2010 (ISBN 978908964088 8)

Diah Ariani Arimbi: Reading Contemporary Indonesian Muslim Women Writers. Representation, Identity and Religion of Muslim Women in Indonesian Fiction

Monographs 3, 2009 (ISBN 978908964089 5)

Sam Wong: Exploring 'Unseen' Social Capital in Community Participation. Everyday Lives of Poor Mainland Chinese Migrants in Hong Kong

Monographs 2, 2007 (ISBN 978905356034 I)

Marleen Dieleman: The Rhythm of Strategy. A Corporate Biography of the Salim Group of Indonesia

Monographs I, 2007 (ISBN 978905356033 4) 


\section{Edited Volumes}

Sebastian Bersick and Paul van der Velde (eds.): The Asia-Europe Meeting: Contributing to a New Global Governance Architecture. The Eighth ASEM Summit in Brussels (2010)

Edited Volumes I5, 2OII (ISBN 9789089643438 )

Derek Heng and Syed Muhd Khairudin Aljunied (eds.): Singapore in Global History

Edited Volumes I4, 2OII (ISBN 978908964324 7)

Philip Hirsch and Nicholas Tapp (eds.): Tracks and Traces. Thailand and the Work of Andrew Turton

Edited Volumes I3, 20IO (ISBN 978908964249 3)

Philip F. Williams (ed.): Asian Literary Voices. From Marginal to Mainstream

Edited Volumes I2, 20Iо (ISBN 978908964092 5)

M. Parvizi Amineh (ed.): State, Society and International Relations in Asia. Reality and Challenges

Edited Volumes II, 2010 (ISBN 978905356794 4)

Huhua Cao (ed.): Ethnic Minorities and Regional Development in Asia. Reality and Challenges

Edited Volumes IO, 2009 (ISBN 978908964 ०91 8)

Khun Eng Kuah-Pearce and Gilles Guiheux (eds.): Social Movements in China and Hong Kong. The Expansion of Protest Space

Edited Volumes 9, 2009 (ISBN 978908964 I3I I)

Erich Kolig, Vivienne SM. Angeles and Sam Wong (eds.): Identity in Crossroad Civilisations. Ethnicity, Nationalism and Globalism in Asia Edited Volumes 8, 2009 (ISBN 978908964 I27 4)

Friederike Assandri and Dora Martins (eds.): From Early Tang Court Debates to China's Peaceful Rise

Edited Volumes 7, 2009 (ISBN 978905356795 I)

Derek Heng and Syed Muhd Khairudin Aljunied (eds.): Reframing Singapore. Memory - Identity - Trans-Regionalism

Edited Volumes 6, 2009 (ISBN 978908964094 9) 
Hans Hägerdal (ed.): Responding to the West. Essays on Colonial Domination and Asian Agency

Edited Volumes 5, 2009 (ISBN 978908964093 2)

Marianne Hulsbosch, Elizabeth Bedford and Martha Chaiklin (eds.): Asian Material Culture

Edited Volumes 4, 2009 (ISBN 978908964090 I)

Milan J. Titus and Paul P.M. Burgers (eds.): Rural Livelihoods, Resources and Coping with Crisis in Indonesia. A Comparative Study

Edited Volumes 3, 2008 (ISBN 978908964055 o)

Khun Eng Kuah-Pearce (ed.): Chinese Women and the Cyberspace Edited Volumes 2, 2008 (ISBN 978905356 75I 7)

Sebastian Bersick, Wim Stokhof and Paul van der Velde (eds.): Multiregionalism and Multilateralism. Asian-European Relations in a Global Context

Edited Volumes I, 2006 (ISBN 978905356929 0) 
(ICAS) Publications Series

Edited Volumes 16

Jajat Burhanudin is the Executive Director at the Center for the Study of Islam and Society, Jakarta.

Kees van Dijk is emeritus professor of the History of Modern Islam in Indonesia.

As elsewhere in the Islamic world a stricter adherence to Islam has gained strength in Indonesia. Does the image of Islam in Indonesia as a model of moderation still hold? It is a topic of debate in Indonesia itself and abroad. This book is a reflection of this discussion. Besides contributions focusing on the specific characteristics of Indonesian Islam others deal with such diverse topics as Salafi groups and their propaganda, radio stations, Muslim transvestites, the pioneering work of Muslim feminists, and the debate about rules of inheritance and divorce.

"This timely book addresses the issue of the moderate nature of Indonesian Islam and presents a picture which confirm as well as contradict this image, thus showing the complexity of Islam in Indonesia."

Dr. Nico J.G. Kaptein, Leiden University 